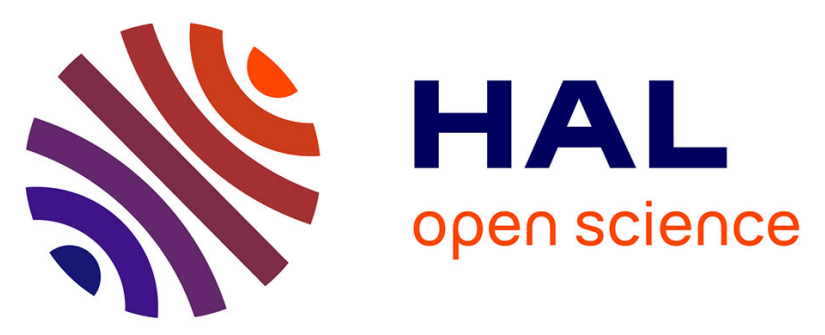

\title{
Deep-water Buccinidae (Gastropoda: Neogastropoda) from sunken wood, vents and seeps: molecular phylogeny and taxonomy
}

\author{
Yu.I. Kantor, N. Puillandre, K. Fraussen, A.E. Fedosov, P. Bouchet
}

\section{To cite this version:}

Yu.I. Kantor, N. Puillandre, K. Fraussen, A.E. Fedosov, P. Bouchet. Deep-water Buccinidae (Gastropoda: Neogastropoda) from sunken wood, vents and seeps: molecular phylogeny and taxonomy. Journal of the Marine Biological Association of the UK, 2013, 93 (8), pp.2177-2195. $10.1017 /$ S0025315413000672 . hal-02458197

\section{HAL Id: hal-02458197 https://hal.science/hal-02458197}

Submitted on 28 Jan 2020

HAL is a multi-disciplinary open access archive for the deposit and dissemination of scientific research documents, whether they are published or not. The documents may come from teaching and research institutions in France or abroad, or from public or private research centers.
L'archive ouverte pluridisciplinaire HAL, est destinée au dépôt et à la diffusion de documents scientifiques de niveau recherche, publiés ou non, émanant des établissements d'enseignement et de recherche français ou étrangers, des laboratoires publics ou privés. 


\title{
Deep-water Buccinidae (Gastropoda: Neogastropoda) from sunken wood, vents and seeps: Molecular phylogeny and taxonomy
}

\section{KANTOR YU.I. ${ }^{1}$, PUILLANDRE N. ${ }^{2}$, FRAUSSEN K. ${ }^{3}$, FEDOSOV A.E. ${ }^{1}$, BOUCHET P. ${ }^{2}$}

\author{
${ }^{1}$ A.N. Severtzov Institute of Ecology and Evolution of Russian Academy of Sciences, Leninski \\ Prosp. 33, Moscow 119071, Russia, \\ ${ }^{2}$ Muséum National d'Histoire Naturelle, Departement Systematique et Evolution, UMR 7138, \\ 43, Rue Cuvier, 75231 Paris, France, \\ ${ }^{3}$ Leuvensestraat 25, B-3200 Aarschot, Belgium
}

\begin{abstract}
Buccinidae - like other canivorous and predatory molluscs - are generally considered to be occasional visitors or rare colonizers in deep-sea biogenic habitats. However, casual observations during tropical deep-sea cruises suggest that associations between buccinids and sunken wood, in particular, are not fortuitous. Enigmatocolus monnieri has been found to co-occur in Madagascar with bathymodiolines, vesicomyids and solemyids, indicating the presence of seeps, and species of Thermosipho gen. nov. have been sampled by submersibles and ROVs, exclusively from hydrothermal vents. A molecular phylogeny (based on CO1, 12S and 28S genes) reveals that buccinid genera potentially associated with sunken wood (Eosipho, Gaillea gen. nov., Calagrassor gen. nov., and Manaria) are closely related to taxa from vents (Thermosipho gen. nov.) and seeps (Enigmaticolus). The anatomy of several dissected species did not reveal any special trait that could be interpreted as a special adaptation to biogenic substrates. Buccinids from sunken wood are most diverse in the Indopacific centre of marine biodiversity, the "Coral Triangle", at depths between 100 and 1000 meters, with numerous species still undescribed.
\end{abstract}

Keywords: Buccinidae, Gastropoda, vents, seeps, sunken wood, taxonomy, molecular phylogeny, anatomy

\section{INTRODUCTION}

Biogenic substrates - comprising whale and wood falls, sulphide-rich emissions, and methane seeps - are home to a taxonomically and phylogenetically diverse molluscan fauna that includes representatives from almost all the classes (Desbruyères et al., 2006; Warén, 2011). Typically, molluscs that are ecologically endemic to biogenic substrates graze the bacterial film or fungi, filter bacteria, or live symbiotically with bacteria (Wolff, 1979; Marshall, 1985, 1986, 1988; Warén \& Bouchet, 2001). Carnivorous and predatory molluscs are usually assumed to be mere "visitors" in reducing environments, where they are thought to be attracted by the high biomass of these communities (for review see Sasaki et al., 2010).

The vast majority of predatory snails in biogenic substrates belong to two neogastropod superfamilies - Conoidea and Buccinoidea. At least one genus of Raphitomidae (Conoidea), Phymorhynchus Dall, 1918, appears to be found preferentially in hydrothermal vent fields and seeps (Warén \& Bouchet, 1989, 1993, 2001; Beck, 1996), and may be an ecological endemic. The other family of carnivorous gastropods well represented in such reducing environments is the family Buccinidae. The reasons why some buccinids show a preference for biogenic substrates are unclear. The anatomy has been examined (Harasewych \& Kantor, 2002) by dissection for a single species from seeps, Buccinum thermophilum, and no morphological characteristic was standing out. In other groups of molluscs, and in particular in mussels from chemosynthetic environments, it has been proposed that several morphological or physiological features, such as the large size of the animal or the presence of endosymbionts, may explain their 
adaptation to extreme environments (Lallier, 2006). However, recent literature also revealed that a lack of taxonomic knowledge prevents any robust analysis of the evolution of these groups, and in particular the role of the potential adaptations to organic substrates (Génio et al., 2012).

At least two genera of deep-water tropical Buccinidae - Eosipho Thiele, 1929, and Manaria E.A. Smith, 1906 - are often found on sunken wood (Warén, 2011), and several species were described either from sunken wood [Eosipho aldermenensis (Powell, 1971)], or from vents and seeps [Eosipho desbruyeresi Okutani \& Ohta, 1993, E. auzendei Warén \& Bouchet, 2001 and E. canetae (Clench \& Aguayo, 1944)]. Calliloncha nankaiensis Okutani \& Iwasaki, 2003, was also described from abyssal seeps off Japan (Okutani \& Iwasaki, 2003) and a species of Kryptos has recently been described from methane seeps off Chile (Fraussen \& Sellanes, 2008). The recent finding of living specimens of the monotypic genus Enigmaticolus Fraussen, 2008 - originally described based on empty shells off NW Madagascar together with bivalves typically associated with methane seeps or hydrothermal vents (Bathymodiolus, Vesicomya and Solemya), adds another taxon to the list of buccinids from reducing environments, and allows a critical evaluation of its relationships to Eosipho. A further two species of Neptunea Röding, 1798, three species of Bayerius Olsson 1971, and at least three species of Buccinum Linnaeus, 1758 are also found "near" seeps or vents (Warén \& Bouchet, 2001; Harasewych \& Kantor, 2002). Juvenile specimens (less than $15 \mathrm{~mm}$ ) of Aulacofusus hiranoi (Shikama, 1962) and A. coerulescens (Kuroda and Habe in Habe, 1961) were found on pieces of sunken wood in bathyal depths off Japan (Hasegawa, 2009).

The regular finding of buccinids on sunken wood in tropical deep water suggests that these are more than occasional "guests". However, the phylogeny of the family Buccinidae is poorly understood, and we do not know whether the species occurring in vent, seeps and biogenic substrates form a monophyletic radiation, or whether they represent offshoots of various buccinid lineages. The purpose of the present paper is thus twofold:

(1) Describe the anatomical diversity of Buccinidae from sunken wood and seeps as a contribution towards a better understanding of the evolution of this particular fauna;

(2) Provide, on the basis of molecular phylogenetic methods, the genus-level framework of the "Eosipho" and "Manaria"-like species associated with sunken wood and other organic substrates, for a forthcoming species-level revision.

\section{MATERIAL AND METHODS}

\section{Material}

The material that forms the basis for this paper was collected during several deep-sea expeditions conducted by the Muséum National d'Histoire Naturelle (MNHN) and Institut de Recherche pour le Développement (IRD) in the Indo-West Pacific, notably: (1) Philippines. PANGLAO 2005 cruise on board M/V DA-BFAR associating the University of San Carlos, MNHN (co-PI Philippe Bouchet) and the Philippines Bureau of Fisheries and Aquatic Research (BFAR; co-PI Ludivina Labe) (see Richer de Forges et al. 2009)); the AURORA 2007 cruise also on board M/V DA-BFAR associating the National Museum of the Philippines (NMP, co-PI Marivene Manuel), MNHN (co-PI Philippe Bouchet) and BFAR. (2) Vanuatu. Material from the MNHNIRD-PNI Santo 2006 expedition (see Bouchet et al. 2011). (3) Solomon Islands. SALOMON 2 2004 cruise (see Bouchet et al. 2008); (4) Madagascar. MIRIKY 2009 cruise off NW Madagascar as part of the "Our Planet Reviewed" Mozambique-Madagascar expeditions. Specimens were preserved in 95 or $98 \%$ ethanol specifically for molecular analysis by clipping pieces of the head-foot from anesthetized specimens, thus keeping the shell and the rest of the body intact for morphological analyses. All specimens used for molecular studies (Table 1) were individually catalogued and deposited in MNHN, and the corresponding sequences are deposited in BOLD (Barcode of Life Datasystem) and GenBank. Two tissue samples of "Eosipho" auzendei from SMNH were provided by Anders Warén. 


\section{DNA extraction, amplification and sequencing}

Genomic DNA was extracted from a piece of foot or from digestive gland tissue, using the 6100 Nucleic Acid Prepstation system (Applied Biosystem). Three genes were amplified: the "barcoding" fragment of the Cytochrome Oxidase I (COI) mitochondrial gene, using universal primers LCO1490 and HCO2198 (Folmer et al., 1994); a fragment of the mitochondrial rRNA 12S gene, using the primers 12S1 and 12S3 (Simon et al., 1991); and a fragment of the nuclear rRNA 28S gene, using the primers C1 and D2 (Jovelin \& Justine, 2001). All PCR reactions were performed in $20 \mu \mathrm{l}$, containing $3 \mathrm{ng}$ of DNA, $10 \mathrm{X}$ reaction buffer containing $15 \mathrm{mM} \mathrm{MgCl}_{2}$, $0.26 \mathrm{mM}$ dNTP, $0.3 \mu \mathrm{M}$ of each primer, 5\% DMSO, $1 \mathrm{mg} / \mathrm{ml}$ BSA, and 1 unit of QBiotaq (MPBiomedicals). Amplification consisted of an initial denaturation step at $95^{\circ} \mathrm{C}$ for 5 min, followed by 35 cycles of denaturation at $95^{\circ} \mathrm{C}$ for $1 \mathrm{~min}$, annealing at $50^{\circ} \mathrm{C}$ for the COI gene, $54^{\circ} \mathrm{C}$ for the $16 \mathrm{~S}$ and $56^{\circ} \mathrm{C}$ for the $28 \mathrm{~S}$ genes for $30 \mathrm{sec}$, followed by extension at $72^{\circ} \mathrm{C}$ for 30 sec. The final extension was at $72^{\circ} \mathrm{C}$ for $5 \mathrm{~min}$. PCR products were purified and sequenced by the Eurofins sequencing facility. Both directions were sequenced to confirm accuracy of each sequence.

\section{Phylogenetic analyses}

Sequences were manually (COI) or automatically (16S and 12S) aligned using Muscle online (www.ebi.ac.uk/Tools/msa/muscle/). Phylogenetic analyses were performed using MrBayes (Huelsenbeck et al., 2001), running two parallel analyses, consisting each of eight Markov chains of 30,000,000 generations with a sampling frequency of one tree each ten thousand generations. The number of swaps was set to 5 , and the chain temperature at 0.02 . Parameters of the substitution model were estimated during the analysis (6 substitution categories, a gammadistributed rate variation across sites approximated in four discrete categories and a proportion of invariable sites). A different model of substitution was applied for each codon position of the COI gene. A concatenated dataset of the three genes (COI, 12S and 28S) was build after checking for congruency of the three trees obtained with each gene; five independent partitions were defined (three codon positions of the COI gene, 12S, and 28S). Convergence of each analysis was evaluated using Tracer 1.4.1 (Rambaut \& Drummond, 2007) to check that ESS values were all greater than 200 (default burning). Metula was identified as the most closely related genus to the group that included the Eosipho and Mannaria group, based on an extended dataset of $\sim 500$ COI sequences of Buccinidae from the Indo-Pacific (unpublished data). We thus used a specimen of Metula sp. as closely related outgroup. A second outgroup, Conasprella eugrammata f. nereis Petuch, 1979 was used as distant outgroup to artificially root the tree (Table 1).

\section{RESULTS}

\section{Molecular analysis}

Separate analyses of CO1 (Figure 1), 12S (Figure 2) and 28S (Figure 3) genes revealed slightly different topologies, but most deep nodes were only weakly supported and no supported incongruences were found. The analysis of the concatenated dataset clearly helped in defining major lineages within the Manaria-Eosipho group and the relationships between them (Figure 4). A first clade was retrieved (Posterior probabilities PP $=1$ ) that includes all the Manaria species, of which four revealed by DNA sequences are potentially new species. This clade was also found with the $12 \mathrm{~S}(\mathrm{PP}=0.40)$ and the $28 \mathrm{~S}(\mathrm{PP}=0.99)$ genes. In all analyses the species traditionally placed in Eosipho were spread in four deeply divergent lineages. One of them includes E. smithi and an undescribed species as suggested by the COI tree. Because E. smithi is the type species of the genus, the name Eosipho remains attached to this clade. A second lineage corresponds to "Eosipho" auzendei, a species from hydrothermal vents. It is sister-group to seep species, Enigmaticolus monnieri, but this relationship is not supported in any of the trees, and 
these species differ significantly both conchologically ("Eosipho" auzendei has more ovate shell with much shorter spire and lacks of distinct spiral cords on the shell base and subsutural ramp) and anatomically (different morphology of [proboscis retractors and more poorly developed valve of Leiblein - see below). Thus, "Eosipho" auzendei cannot be included in Enigmaticolus, and we propose the name Thermosipho gen. nov. A third lineage includes only one species, "Eosipho" coriolis. This species is the sister-group to all the other species, excluding Enigmaticolus monnieri and Thermosipho auzendi. There is no generic name available for this branch and therefore a new genus is proposed, Gaillea gen. nov. The last lineage includes two species in our trees, "Eosipho" aldermenensis and one undescribed species. This clade is a sister group to Manaria in the combined and 12S trees. In any case it can not be included in Manaria on morphological grounds (shell and radula), and the new genus Calagrassor gen. nov. is proposed for this clade.

\section{Taxonomy}

Class GASTROPODA Cuvier, 1795

Clade NEOGASTROPODA Wenz, 1938

Family BUCCINIDAE Rafinesque 1815

Because our dataset is taxonomically focused, and because the suprageneric phylogeny of the Buccinoidea, including Buccinidae, is still far from resolved (Kantor et al., 2012), we do not attribute any rank or name to the clade that includes the genera under consideration, pending a more robust and comprehensive phylogeny of the group. The species-level taxonomy will be discussed elsewhere (Fraussen \& Stahlschmidt, in preparation).

Genus Enigmaticolus Fraussen, 2008

Enigmaticolus Fraussen, 2008: 75-77.

TYPE SPECIES. Enigmaticolus monnieri Fraussen, 2008, by original designation.

DESCRIPTION

Shell large (Figure $5 \mathrm{~A}-\mathrm{F}$ ), up to $100 \mathrm{~mm}$, usually thick, solid. Colour brownish, occasionally purplish. Periostracum thick, dark brown, occasionally shiny or with metallic appearance, adherent. Shell broad fusiform, spire moderately high, siphonal canal short, broad, open. Protoconch and upper spire whorls decollate already in early, subadult age. Whorls convex, suture narrow canaliculate, subsutural ramp pronounced, rather broad, concave. Sculpture consisting of prominent, closely spaced, axial ribs spanning suture to suture on upper spire whorls, and gradually becoming obsolete on lower whorls. Spiral sculpture of inconspicuous cords; on siphonal canal, cords prominent, flattened, closely spaced, delimitated by narrow groves. Aperture large, slightly less than $1 / 2$ of shell length, oval. Outer lip thick, slightly recurved outwards in adults, sometimes crenulated in abapical part. Callus narrow, but thick, overlaying parietal region and columella. Canal short, rather broad.

Operculum thick, corneous, usually dark brown; slightly smaller than aperture, semi-oval, nucleus terminal.

Radula (Figure 6 E-F): rachidian teeth with anteriorly strongly arched base and with three closely spaced medium long, nearly equal, cusps. Two lateral cusps more raised over base, forming narrow concavity, possessing median cusp. Lateral teeth with two strong cusps, inner one shorter, but slightly broader than outer one.

ANATOMY (Enigmaticolus monnieri). 
Two specimens of Enigmaticolus monnieri were dissected, from MIRIKY, st. CP3270, 15'31'S,

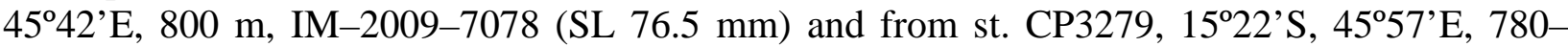
1020 m, IM-2009-7079 (SL 99.4 mm).

Soft tissues (Figures 6 A-D, based on specimen IM-2009-7078) comprise approximately 31/2 whorls. Mantle cavity spans just under $1 / 2$ whorl, kidney $1 / 4$ whorl, digestive gland and gonad just under $2 \frac{1}{2}$ whorl. Columellar muscle short, broad, and thick, comprising one whorl, attached to shell at rear of mantle cavity. Foot large, strongly folded, narrowly rectangular ( $\mathrm{L} / \mathrm{W} \approx 2$ ). Body colour yellowish tan, without pigmentation. Head large with long, medium thick tapering tentacles (Figure 6C, tn), without pronounced neck. Eyes large, on distinct rounded lobes at the base of tentacles, rather submerged into lobes. Nephridium brownish, with small and narrow nephridial gland (Figure 6B, ng), which has thin semi-transparent walls. Digestive gland greenish, lobes fused without visible border. Externally, ovary not distinguishable from digestive gland. Operculum thick, brownish, elongate-oval, with terminal abraded nucleus and numerous thickened growth lines.

Mantle cavity (Figure 6D): Mantle thick, ctenidium and osphradium hardly visible through its wall. Mantle cavity of medium width (L/W 1.2), mantle edge slightly thickened, non-serrated. Siphon medium long, free, muscular, extending substantially beyond mantle edge. Siphonal fold at siphon base well developed. Osphradium (Figure 6D, os) small ( $\sim 0.35 x$ mantle cavity length), narrow, greenish, bipectinate, with thin osphradial nerve. Ctenidium (Figure 6D, ct) large, very wide, spanning about $3 / 4$ of mantle cavity length. Ctenidial lamellae simple triangular in shape, very low (width/height ratio 5). Hypobranchial gland lacking distinct folds, partially overlaying rectum, covered by thick layer of mucus. Entire mantle covered by thick mucus layer.

Anterior foregut (Figure 7 A-B) (based on the specimen IM-2009-7079). Proboscis in inverted position medium long, ca. $30 \mathrm{~mm}$ in length (ca 30\% of SL, 60\% of AL), occupying entire rhynchocoel, with slightly folded walls, unpigmented; slightly narrowing towards base of rhynchocoel. Mouth in shape of triangular opening, typical for Buccinidae. Proboscis retractor muscles numerous, powerful, arranged in two lateral symmetrical bundles, extending from midlength of rhynchodaeum forward along entire anterior half of rhynchodaeum. Free parts of retractors short and attached to roof of anterior haemocoel, bending posteriorly at base and fusing with walls of rhynchodaeum, forming its outer layer. Rhynchodaeum medium thick, slightly thinner in anterior part, its internal wall medium folded.

Odontophore large, $75 \%$ of proboscis length, occupying most of the proboscis volume, and compressing the anterior oesophagus dorso-ventrally, so that it becomes narrowly ovate. Odontophoral cartilages constituting about half of odontophore length $(11 \mathrm{~mm})$, fused in anterior $1 / 3$ of their length and separated posteriorly.

Salivary glands loose, fused without visible border, with chinked surface, creamy white and brownish where they adjoin gland of Leiblein, and covering poorly pronounced valve of Leiblein and larger part of circumoesophageal nerve ring. Salivary ducts rather thin, straight, joining oesophagus shortly after leaving gland, and following between ventral surface of oesophagus and rhynchodaeum, completely concealed by former, hardly discernible in posterior part of inverted proboscis among numerous thin muscle fibres.

Gland of Leiblein large, grey-brown, bulky, broadly tubular and folded anteriorly, where it is more intensively coloured. Folds of gland in anterior part encompassing large right salivary gland. Posterior part of gland laterally compressed and tightly attached to posterior oesophagus by connective tissue fibres. Partitions of gland better seen in posterior part. In anteriormost part, gland narrowing to form short distinct duct, opening into mid-oesophagus significantly posterior to nerve ring.

Anterior oesophagus rather muscular and attached to rhynchodaeum by numerous muscular fibres, oesophagus completely covering and hiding salivary ducts. Two thick proboscis nerves 
follow on both sides of thick blood vessel between dorsal side of oesophagus and rhynchodaeum. Valve of Leiblein pyriform, slightly broader than oesophagus, mostly covered by right salivary gland that is tightly attached to valve. Glandular pad seen through walls of valve. Midoesophagus rather long, but thin walled. Border between mid- and posterior oesophagus marked by distinct but short duct of gland of Leiblein. Posterior oesophagus flaccid, laterally compressed and forming distinct outgrowth in its posterior part.

Stomach (Figure 7C) not large, spanning ca 1/3 whorl, U-shaped, posterior mixing area very short, hardly discernible. Posterior oesophagus and stomach inside lined with orange-brownish epithelium. Posterior oesophagus thick and broad. Posterior duct of digestive gland large, situated at entrance of oesophagus into the stomach. Anterior duct shifted anteriorly, marking transition to intestine. Due to preservation conditions internal epithelium slogged off walls of stomach and it was not possible to study its anatomy in details. No stomach content was found.

Specimen IM-2009-7079 was an adult male, penis long, club-shaped on top with very tiny conical seminal papilla (Figure 7 D).

\section{INCLUDED SPECIES}

Enigmaticolus monnieri Fraussen 2008. Type locality: Mozambique Channel, Madagascar, off Tulear, trawled by commercial fishery vessels (shrimpers), $800 \mathrm{~m}$ deep.

There are several still undescribed species in the East China Sea (China) and the western and southwestern Pacific (Japan, Philippines, New Caledonia, Fiji and Lau Basin), descriptions of which are now in preparation (Fraussen \& Stahlschmidt, in preparation).

\section{REMARKS}

Enigmaticolus is most similar to Thermosipho gen. nov. and differs by a longer and more pronounced siphonal canal, the presence of spiral sculpture, and a distinctly set-off subsutural ramp, the presence of axial folds in the subsutural area in subadult and adult whorls, and a larger operculum.

In Madagascar, E. monnieri was trawled alive in hauls on the sedimentary cone of the river Betsibuka, with an associated fauna including bathymodiolines, vesicomyids and solemyids, suggesting the presence of seeps.

\section{Genus Thermosipho gen. nov.}

(Figure 1(2))

TYPE SPECIES. Eosipho auzendei Warén \& Bouchet, 2001.

\section{DESCRIPTION}

Shell medium to large, up to $70 \mathrm{~mm}$, thin to medium thick, solid. Colour brownish to dark brown. Periostracum thick, orange to dark brown, forming dense axial lamellae, but usually smooth due to abrasion except near suture. Suture deeply impressed, not canaliculate. Shape broadly fusiform, spire moderately short. Protoconch and upper spire whorls decollate already at early subadult age. Whorls weakly convex, without subsutural ramp. Axial folds present only on earliest whorls and absent in most adults and subadults. Spiral sculpture of very weak inconspicuous cords or absent. Aperture large, oval, more than half of shell length (up to 0.7 of SL in juveniles). Outer lip thin to rather thick, slightly reflected outwards in adults. Callus narrow, overlaying parietal region and columella. Canal very short, broad.

Operculum corneous, usually light to dark brown, oval, occupying about half of aperture length, nucleus terminal.

Radula (illustrated by Warén \& Bouchet, 2001: Figure 39A for T. auzendei and by Okutani \& Ohta, 1993: Figure 5 for T. desbruyeresi): rachidian teeth with base strongly arched anteriorly 
and with three closely spaced, medium to long, nearly equal, cusps. Two lateral cusps more raised over base, forming narrow concavity, possessing median cusp. Lateral teeth with two strong cusps, inner one shorter, stronger curved and slightly broader than outer one.

\section{ANATOMY (Thermosipho auzendei)}

The dissected earlier paratype 2 of $T$. auzendei was reexamined. Mantle cavity morphology very similar to E. monnieri, differing in slightly larger ctenidium.

Anterior foregut similar to E. monnieri. Instead of series of lateral proboscis retractors subequal in size, pair of very large more posterior retractors, branching near tip, attached to roof of body haemocoel. Several smaller retractors attached to rhynchodaeum anterior to major retractors. Gland of Leiblein even larger than in E. monieri, very long, broadly tubular and folded several times, forming very voluminous mass which spans on ventral side of rhynchodaeum anteriorly. In anteriormost part gland becomes narrower and opens into midoesophagus by narrow duct significantly posterior to nerve ring. Valve of Leiblein very poorly pronounced, hardly discernible from oesophagus.

\section{REMARKS}

Thermosipho gen. nov. is most similar to Enigmaticolus. The two genera cluster together in the molecular trees, although without significant support (PP only 0.81 in the three genes tree). They have similar radulae and anatomy (see below). Nevertheless, Thermosipho differs from Enigmaticolus in its more ovate shell with higher last whorl, shorter siphonal canal, absence of distinct spiral cords on the shell base and absence of subsutural ramp.

\section{INCLUDED SPECIES}

Thermosipho auzendei (Warén \& Bouchet, 2001) comb. nov. Type locality: East Pacific Rise, Rehu site, $17^{\circ} 24.85^{\prime} \mathrm{S}, 113^{\circ} 12.15^{\prime} \mathrm{W}, 2578 \mathrm{~m}$, vent.

Thermosipho desbruyeresi (Okutani \& Ohta, 1993) comb. nov. [original combination: Eosipho desbruyeresi]. Type locality: BIOLAU 89 dive 06, 2313'S, 176³8'W, $1750 \mathrm{~m}$, vent). Synonym: Eosipho desbruyeresi nipponensis Okutani \& Fujiwara, 2000. Type locality: Okinawa Trough, Iheya Ridge, North Knoll, Shinkai 2000 Dive 1112, 2747.180’N, 12654.149’E, 1049 $\mathrm{m}$, vent.

\section{ETYMOLOGY}

Thermosipho gen. nov. is named after thermae (Latin), the hot bath of the Romans, in reference to the habitat of the type species associated with hydrothermal vents (black smokers); rendered as thermo- for euphonic reasons; in combination with -sipho, a name that is in use for many cold-water fusiform buccinids.

Genus Eosipho Thiele, 1929

(Figure 1(4), (5))

Sipho (Eosipho) Thiele, 1929: 307.

TYPE SPECIES. Chrysodomus (Sipho) smithi Schepman, 1911, by original designation.

DESCRIPTION

Shell large, up to $75 \mathrm{~mm}$, rather thick in adults, occasionally thin but solid, white. Periostracum thin, olive, often peeling and retains between spiral cords. Shape semi-ovate, rather oviform, broad with rather high spire and short but distinct siphonal canal. Protoconch eroded in all studied specimens, consisting of $13 / 4$ to 2 whorls. Teleoconch whorls poorly convex, without pronounced shoulder. Teleoconch with dominant spiral sculpture. Spiral cords flattened, on later 
whorls bilirate. Interspaces variable, narrow to broad, usually fine groove. Axial sculpture weak, on upper spire whorls only, or absent by erosion; lower spire whorls and body whorl without traces of axial sculpture. Aperture large, usually about $1 / 2$ of shell length, occasionally larger. Outer lip thick in adults, slightly curling outwards with a row of moderately broad, flattened knobs along edge.

Radula (illustrated by Bouchet \& Warén, 1986: Figure 15): rachidian teeth with rectangular base, shallowly arched anteriorly and with three close spaced medium long cusps, central slightly longer, emanating from posterior edge. Lateral teeth with two strong cusps, inner narrower and slightly shorter than outer.

\section{INCLUDED SPECIES}

Eosipho smithi (Schepman, 1911) (Type locality: Indonesia, north of Pulau Talisei, Celebes Sea, Siboga stn 122, 0158’N, 12500’E, 1165-1264 m) has a broad Indo-West Pacific distribution from East Africa (Mozambique Channel) in the west, along Indonesia and Philippines to southern Japan, Solomons and Fiji in the east.

According to COI tree, Eosipho includes at least one more unnamed species (Eosipho sp. 1, IM2007-32921) from lower bathyal depths in the Solomon Islands. The sequenced specimen is immature (shell length $24.7 \mathrm{~mm}$ ) and axial ribs are present on the last whorl.

Genus Gaillea gen. nov.

(Figure 1(3))

TYPE SPECIES. Eosipho coriolis Bouchet \& Warén, 1986.

\section{DESCRIPTION}

Shell of medium to large size, up to $70 \mathrm{~mm}$, thick and solid, Colour white. Periostracum thin, adhering, light olive, forming irregularly spaced axial lamellae and occasionally short bristles. Shape broad, fusiform, to semi-oval with attenuated, but distinct, siphonal canal. Protoconch usually eroded in both adult and juvenile species; pointed, higher than broad. Teleoconch whorls weakly convex with angulated shoulder, subsutural slope straight. Sculpture with some reticulate pattern; spiral sculpture fine, especially on abapical spire whorls and body whorl, variable, usually consisting of spiral cords separated by deep and narrow interspaces or grooves; along shoulder, a single, more pronounced, primary spiral cord accentuating shoulder angulation. Axial sculpture weak, consisting of low axial ribs along on adapical part of whorls, usually slightly broader, but weaker, on body whorl. Aperture oval to round. Columella gently curved; transition to siphonal canal usually strongly curved. Callus thin, overlaying spiral sculpture and outer shell layer of parietal region, glossy, smooth. Outer lip usually thin, occasionally thick; edge sharp.

Radula (illustrated by Bouchet \& Warén, 1986: figs. 14, G. engonia; 15, G. coriolis): rachidian teeth with rectangular base, shallowly arched anteriorly, and with three broadly spaced, medium long, cusps, central equal in length to, or slightly longer than, lateral ones, emanating from posterior edge. Lateral teeth with two strong cusps, inner narrower and slightly shorter than outer.

\section{REMARKS}

Species belonging to Gaillea gen. nov. are most similar to Eosipho and Calagrassor gen. nov. They differ from Eosipho in slightly carinated whorl profile; finer spiral sculpture consisting of broader spaced and narrower cords alternating in size; presence of finer spiral cords on the subsutural slope and better pronounced axial ribs which are present on the last whorl but absent on the base.

From Calagrassor gen. nov., Gaillea differs by its broader shell, with usually constricted base, thinner spiral cords with broader interspaces, presence of a stronger spiral cord along the 
shoulder accentuating the shoulder angulation, sharper apex with pointed protoconch, and slightly larger adult size.

\section{INCLUDED SPECIES}

Gaillea coriolis (Bouchet \& Warén, 1986) comb. nov. Type locality: Philippines, northern Mindoro, SE Ambil Island, MUSORSTOM 2, stn 81, 13³4’ N, 120³1’E, 856-884 m.

Gaillea engonia (Bouchet \& Warén, 1986) comb. nov. (Original combination: Eosipho engonia). Type locality: northern Mozambique Channel, Vauban st. 139, 1350's, 47³7’E, 850-1125 m.

On the basis of shell shape with angulated shoulder and shell sculpture, Gaillea tosaensis (Okutani \& Iwahori, 1992) comb. nov. (original combination: Eosipho tosaensis) is also probably congeneric. Type locality: Tosa Bay, Japan, $780 \mathrm{~m}$.

Finally, Gaillea canetae (Clench \& Aguayo, 1944) comb. nov. (original combination: Buccinum canetae) appears to belong to Gaillea based on the shell and radula (illustrated by Warén and Bouchet, 2001, figure 39d). Type locality: off La Havana, Cuba, 23¹2'30"N, 82¹2'W, 240-300 fathoms.

\section{ETYMOLOGY}

The new genus is named after Françoise Gaill, a long-time companion of P. Bouchet during deep-sea expeditions with CNEXO, and later IFREMER, and in recognition for her interests in chemosynthetic environments and sunken wood.

\section{Genus Calagrassor gen. nov.}

(Figure 1(13) (14))

TYPE SPECIES. Cantharus aldermenensis Powell, 1971.

\section{DiAGNOSIS}

Shell small to medium in size (adult length from 9 to $45 \mathrm{~mm}$ ), solid, usually rather thin. Colour white. Periostracum velvety, forming fine axial lamellae or bristles; occasionally smooth, often well adherent to shell. Shape oval with short siphonal canal. Protoconch usually eroded, juveniles with a moderately small, naticoid protoconch, width exceeds height, consisting of $1 \frac{1 / 4}{4}$ to $1 \frac{1}{2}$ smooth, convex whorls. Teleoconch whorls evenly weakly convex. Spiral sculpture dominant, usually of broad, flattened spiral cords separated by deep interspaces, narrower than or equal to cords width. Axial sculpture usually weak, pronounced on adapical spire whorls, usually absent on body whorl, ranging from broad, flattened ribs to narrow and moderately sharp ones. Aperture oval, adapically usually slightly pinched. Columella gently curved. Callus thin, narrow, formed by dissolution of sculpture and outer shell layer of preceding whorl, glossy, smooth. Outer lip usually thin, occasionally thick, edge sharp, occasionally with internal lirae or knobs.

Radula (illustrated by Bouchet \& Warén, 1986, fig. 13): rachidian teeth with rectangular base, shallowly arched anteriorly, with three closely spaced, long cusps, central much longer than lateral ones, emanating from posterior edge. Lateral teeth with two strong, long cusps, inner narrower and much shorter than outer. In C. zephyrus, there is an additional very thin and short intermediate cusp on lateral teeth.

\section{ANATOMY (Calagrassor aldermenensis)}

The anatomy of a specimen collected off Madagascar (MIRIKY, st. CP 3290, 14²47'S, 47²6' E, 409-425 m; shell length $19.1 \mathrm{~mm}$ ) was examined.

Soft tissues (Figure $8 \mathrm{C}-\mathrm{D}$ ) comprise just under 3 whorls. Mantle cavity spans just under $1 / 2$ whorl, kidney $1 / 4$ whorl, digestive gland and gonad just under $1 \frac{1}{2}$ whorl. Columellar muscle extending over $1 \frac{1}{2}$ whorl, broad and thick, attached to shell posteriorly to rear of mantle cavity, subdivided into three bands, lower one longest. Foot large, contracted, sole broadly oval ( $\mathrm{L} / \mathrm{W} \approx$ 
1.4). Body colour yellowish tan, unpigmented. Head medium sized, with long, medium thick, cylindrical tentacles, rounded at tip (Figure 8D, tn), without pronounced neck. Eyes large, on distinct rounded lobes at base of tentacles. Nephridium light brownish, with few ramifying trabecules seen through wall, with small and narrow nephridial gland (Figure $9 \mathrm{C}$, ng). Digestive gland light brownish, clearly bilobed; lobes separated by testis. Posterior lobe narrow, spanning about $1 / 3$ whorl, overlaid by testis, which occupies most of visceral mass. Operculum thin, yellow, transparent, elongate-oval, with abraded terminal nucleus and numerous thin growth lines.

Mantle cavity (Figure $8 \mathrm{E}$ ). Mantle thin, ctenidium and osphradium clearly seen through its wall. Mantle cavity nearly square (L/W 1.1), mantle edge slightly thickened, serrated in correspondence with spiral cords. Siphon not long, free, muscular, only slightly extending beyond mantle edge. Siphonal fold well developed at base of siphon. Osphradium large $(\sim 0.5 \mathrm{x}$ mantle cavity length), as broad as ctenidium, brownish, bipectinate, with thick osphradial nerve. Ctenidium large, medium wide, spanning about $3 / 4$ of mantle cavity length. Ctenidial lamellae simple, right-angled triangular in shape, very low. Hypobranchial gland lacking distinct folds, partially overlaying rectum, covered by thick layer of mucus. Entire mantle cavity covered with thick mucus layer. Rectum rather short, slightly over half mantle length, terminating in anus without distinct papilla.

Anterior foregut (Figure 9 A-B). Proboscis in inverted position folded within the rhynchocoel, long, ca. $8.5 \mathrm{~mm}$ in length (ca $45 \%$ of SL, equals AL), occupying only posterior part of rhynchocoel, with folded walls, unpigmented, of approximately even diameter along its length. Slit-shaped mouth. Rhynchodaeum thick-walled and very narrow in anterior half, and thinwalled, transparent and spacious posteriorly, where folded proboscis contained. [It should be noted that, in several dissected specimens from Vanuatu, the proboscis was not folded within the rhynchodaeum.] Two pairs of proboscis retractor muscles, large and thick, attached approximately to mid-length of rhynchodaeum. Thin flat band-like transparent muscle originating at base of posterior pair of major retractors (Figure $9 \mathrm{~A}, \mathrm{rm}$ ), attached to posterior part of the rhynchodaeum, probably folding and contracting rhynchodaeum.

Odontophore minute, about $1.5 \mathrm{~mm}$ long (ca $20 \%$ of proboscis length).

Salivary glands creamy white, with slightly chinked surface, fused without visible border, adjoining gland of Leiblein, oesophagus and valve of Leiblein and larger part of circumoesophageal nerve ring. Salivary ducts rather thin, nearly straight, and joining oesophagus in front of valve of Leiblein shortly after leaving it, and then following tightly attached to oesophagus by connective tissue, not seen exteriorly. Gland of Leiblein large, brown, bulky lobular, and voluminous anteriorly, where it is more intensively coloured, encompassing in anterior part most of left salivary gland. Posterior part of gland laterally compressed, with semitransparent walls and mostly lacking glandular tissue.

Anterior oesophagus rather muscular, narrow, and attached to rhynchodaeum by numerous muscular fibers. Thick proboscis nerve follows between dorsal side of oesophagus and rhynchodaeum. Valve of Leiblein well pronounced, approximately twice broader than anterior oesophagus, long and nearly cylindrical, with mucous pad well seen through its walls. Midoesophagus very short, bordered posteriorly by indistinct short duct of gland of Leiblein. Posterior oesophagus flaccid, laterally compressed and forming distinct outgrowth in its posterior part.

Stomach (Figure 9C) not large, spanning ca 1/3 whorl, U-shaped, posterior mixing area not discernible. Posterior oesophagus broad, of same diameter as stomach. Posterior duct of digestive gland small, situated at entrance of oesophagus into the stomach. Anterior duct slightly shifted anteriorly. Intestine after leaving stomach becoming much narrower as it follows under 
the kidney. Due to preservation, internal epithelium slogged off the walls of the stomach and impossible to study in detail.

\section{REMARKS}

Species of Calagrassor differ from Gaillea in being more slender, with evenly rounded whorls, without angulation. In general shell shape and sculpture, they are most similar to Eosipho and differ in having a smaller protoconch formed by convex whorls, more convex adapical teleoconch whorls, non subdivided spiral cords, and a simple outer lip.

\section{INCLUDED SPECIES}

Calagrassor aldermenensis (Powell, 1971) comb. nov. Type locality: New Zealand, Coromandel, east of Aldermen Islands, 3658'S, 17606' E, 366-475 m.

Calagrassor poppei (Fraussen, 2001) comb. nov. (original combination: Eosipho poppei). Type locality: Philippines, Balicasag Id., 140-400 m.

Calagrassor tashiensis (Lee \& Lan, 2002) comb. nov. (original combination: Colus (Aulacofusus) tashiensis Lee \& Lan, 2002). Type locality: NE Taiwan, around Kue-Shun Is., 400-500 m.

Calagrassor zephyrus (Fraussen, Sellanes \& Stahlschmidt, 2012) comb. nov. (original combination: Eosipho zephyrus Fraussen, Sellanes \& Stahlschmidt, 2012). Type locality: southern Chile, off Chiloé, about 42'S, in $500 \mathrm{~m}$.

A further deep-water $(1764-2150 \mathrm{~m})$ species from the Philippines (Calagrassor sp. 1 in our analysis) will be named elsewhere (Fraussen \& Stahlschmidt, in preparation).

\section{ETYMOLOGY}

From the Latin cala, a piece of wood; and grassor, vagabond. Used as a noun in apposition.

REMARKS

Calagrassor aldermenensis is exclusively found on sunken logs, sometimes in very deep holes, that are exposed when the wood is cut (Figs 8A-B).

Genus Manaria E. A. Smith, 1906

(Fig. $1(6-12))$

Manaria E. A. Smith 1906: 167.

TYPE SPECIES. Manaria thurstoni E. A. Smith, 1906, by original designation.

\section{DESCRIPTION}

Shell medium large to large (adult length from 14 to $80 \mathrm{~mm}$ ), usually thick and solid. Colour chalky white. Shape fusiform with moderately long siphonal canal. Periostracum velvety, forming with fine axial lamellae or bristles, occasionally smooth, well adherent to shell. Protoconch (often eroded even in young specimens) moderately small, of $1 \frac{1}{4}$ to $1 \frac{1 / 2}{2}$ smooth, convex whorls. Teleoconch whorls convex, occasionally with weak, concave subsutural ramp. Suture deep, rarely shallowly canaliculate. Spiral sculpture dominant, variable, usually of well pronounced cords separated by deep interspaces, up to twice as broad as spiral cords but occasionally restricted to sharp grooves. Axial sculpture variable, usually dominant on adapical whorls, weaker or absent on last whorl, ranging from broad, flattened ribs to narrow and sharp ones. Aperture narrow to oval, usually slightly pinched adapically. Columella gently curved, smooth or with one or more weak knobs; callus thin, formed by dissolution of sculpture and outer shell layer of preceding whorl, glossy, smooth or with one or more weak columellar knobs. Outer lip usually thin, occasionally thick, edge sharp, with internal lirae or knobs. 
Operculum corneous, thick, dark to pale brown, semi-ovate, nucleus terminal.

Radula (several species, illustrated by Bouchet \& Warén, 1986: figs 19-24): rachidian teeth with narrow rectangular base (length may exceed width), shallowly to deeply arched anteriorly and with three closely spaced, medium to long, cusps, occupying most of posterior edge of basal plate. Central cusp very slightly longer than lateral ones. Lateral teeth with two strong short cusps, inner slightly shorter than outer; occasionally there can be a vestigial intermediate cusp.

\section{REMARKS}

Manaria differs from other genera under consideration in its generally narrower, fusiform shell, with higher spire and longer siphonal canal, and in well developed axial ribs on all whorls.

\section{SPECIES INCLUDED}

Manaria thurstoni E. A. Smith, 1906. Type locality: India, Gulf of Manar, Investigator stn 333, 06³1'N, 19³9’ E, $730 \mathrm{~m}$.

Manaria brevicaudata (Schepman, 1911) (original combination: Fusus brevicaudatus). Type locality: Flores Sea, Siboga, st. 45, 07²4’S, 118²04'E, 470-475 m.

Manaria kuroharai Azuma, 1960. Type locality: Japan, Tosa Bay, Shikoku Island, 180 m.

Manaria lirata Kuroda \& Habe in Habe, 1961. Type locality: Japan, Ashizuri-misaki, Kochi Pref., Shikoku, $100 \mathrm{~m}$.

Manaria clandestina Bouchet \& Warén, 1986. Type locality: Philippines, Sibuyan Sea, , Musorstom 2 st. 36, $13^{\circ} 31^{\prime} \mathrm{N}, 121^{\circ} 24^{\prime} \mathrm{E}, 570-595 \mathrm{~m}$.

Manaria makassarensis Bouchet \& Warén, 1986. Type locality: Makassar Strait, CoRINDON 2, st. $214,00^{\circ} 31^{\prime} \mathrm{N}, 117^{\circ} 50^{\prime} \mathrm{E}, 595 \mathrm{~m}$.

Manaria formosa Bouchet \& Warén, 1986. Type locality: Mozambique Channel, Vauban, st. 39, $12^{\circ} 46^{\prime} \mathrm{S}, 48^{\circ} 10^{\prime} \mathrm{E}, 495-500 \mathrm{~m}$.

Manaria thorybopus (Bouchet \& Warén, 1986) (original combination: Eosipho thorybopus). Type locality: Mozambique Channel, Vauban, st. 114, 22 $15^{\prime} \mathrm{S}, 4^{\circ} 04^{\prime} \mathrm{E}, 470-475 \mathrm{~m}$.

Manaria chinoi Fraussen, 2005. Type locality: Philippines, Mindanao, off Davao Island, $160 \mathrm{~m}$. and many still unnamed species from the Indo-West Pacific (Fraussen \& Stahlschmidt, in preparation).

\section{DISCUSSION}

\section{Position of buccinids from sunken wood within Buccinoidea}

The dataset analyzed has limitations due to the number of taxa included. A number of species already described were not available for molecular analyses, and many more species are still unnamed judging from traditional shell characters. Furthermore, the sequenced material is biased towards the Indo-West Pacific, and none of the Atlantic species attributed to the group (Fraussen \& Hadorn, 2005) was included in the molecular phylogeny. Nevertheless, a number of conclusions can be significantly drawn. The species included in the analysis were previously classified in Manaria and Eosipho, two genera rather loosely defined based on shell characters, but they actually correspond to six deep molecular lineages that we rank as genera. All share rather a similar radular morphology, with bicuspid lateral teeth and a tricuspid rachidian. Although bicuspid lateral teeth are found in other, obviously non related, genera of Buccinidae (e.g., in Phos, Cominella, and several Antarctic genera) - thus suggesting convergent evolution -, this similarity of radula among several conchologically dissimilar, but phylogenetically related, genera is remarkable. This suggests that, at least in some Buccinoidea the radula is more conservative in terms of morphological variation than the shell.

The molecular dataset recovers as monophyletic Buccinidae that are known (Thermosipho, Enigmaticolus, some Calagrassor) or suspected (Manaria) to inhabit biogenic substrates. Bayerius and Calliloncha nankaiensis (also known to inhabit biogenic substrates; for review see 
Warén \& Bouchet, 2001; Sasaki et al., 2005) may or may not belong to this group. However, several species of Neptunea and Buccinum, also recorded from biogenic substrates certainly do not fall in this clade. This is confirmed by the differences in radulae anatomy (strictly bicuspid lateral teeth in the described genera and tri- or multicuspid in Buccinum and Neptunea, the differences significant enough to attribute genera to different tribes in Buccinidae), as well as unpublished results based on COI sequences. There have thus been several colonization events that brought Buccinidae to live on biogenic substrates, but a single one appears to have diversified into at least six genera which are restricted to such habitats.

Although the clade that includes the genera under consideration is morphologically and, presumably (in the absence of a larger phylogeny of the Buccinidae), molecularly well defined, we abstain from giving it a formal rank and establishing a name for it. Unpublished, and still fragmentary, molecular data on the Buccinidae reveal a complex phylogenetic pattern, in a number of ways contradicting the classification of Buccinoidea adopted by Bouchet \& Rocroi (2005). We therefore consider it premature to give a name and a rank to the clade.

\section{Anatomy and morphological adaptations}

Shell

One of the remarkable characters of the shells of Thermosipho and Enigmaticolus is the very thick periostracum, especially in the former genus, while the inorganic matrix of the shell is relatively thin for such large sizes. In adults, periostracum is usually smooth due to abrasion, but in the youngest specimens it bears axial lamellae. In species of both genera, protoconch and upper teleoconch whorls are decollated, probably as a result of the dissolution of the shell. A thick periostracum could be a protection of the shells in aggressive environmental conditions in the vicinity of vents and seeps. In other genera, the periostracum is also prominent, but not so thick, and is in fact more similar to other deep water non seep-vent buccinids, suggesting the lack of necessity of protecting the shell from dissolution. Also the protoconchs are often eroded, but upper teleoconch whorls are usually intact.

\section{Digestive system and feeding}

As was mentioned in the introduction, the anatomy of a single buccinoid species from biogenic substrates has been examined before this study: Buccinum thermophilum Harasewych \& Kantor, 2002. That species was found to be an active predator and opportunistic scavenger with a broad diet, including vestimentiferans, pycnogonids and polychaetes (Martell et al., 2002). Its anatomy was typical for Buccinum species (Harasewych \& Kantor, 2002), and no anatomical characters were linked to its inhabiting vents environment.

Likewise, the anatomy of Enigmaticolus monnieri and Calagrassor aldermenensis, studied here, is typical for Buccinoidea. Neither their external morphology, nor their digestive system anatomy, suggest any specific adaptation. In Calagrassor aldermenensis, the proboscis is very long and able to coil within the rhynchodaeum, which may be an adaptation for capturing prey hiding in narrow holes and crevices. However, a similar proboscis is found in other Buccinidae from the ambient deep sea, such as in some Aulacofusus and Colus species, as well as in Ancistrolepis (Kantor 1988; Kosyan \& Kantor, 2009). Nothing so far is known about the diet of any of these species. We dissected more than 25 specimens of Calagrassor aldermenensis, but stomach and gut were empty in all of them. One specimen of Enigmaticolus monnieri, when preserved, regurgitated a mass of unidentifiable, partially digested, soft tissues, which may be the tentacles of large sedentary polychaetes; this remains entirely speculative, though, and our attempts to sequence the gut content for the COI gene failed.

So, judging from the foregut anatomy we may suggest that Calagrassor and Enigmaticolus are predators or scavengers, in that respect not differing from other Buccinidae. Apparently, the buccinoid foregut anatomy allows preying on a wide variety of invertebrates without any special morphological adaptations. 


\section{Diversification of Buccinidae on biogenic substrates}

Three major biogenic substrates (hydrothermal vents, methane seeps and sunken wood) are colonized by Buccinidae. It is rather obvious that Thermosipho and Enigmaticolus are really specialized on vents and seeps, since they are collected in numbers only there and not elsewhere. We have much fewer data about actual occurrences of Buccinidae on sunken wood, and hauling a trawl on the bottom is not the best approach to documenting labile associations. In fact, of all the species analyzed herein, only Calagrassor aldermenensis is known to inhabit exclusively sunken logs. It obviously prefers to hide deep inside holes, which would explain why specimens are rarely - if ever - found loose in the bottom residue. By contrast, many other species are often found in the same hauls as sunken wood, but not attached to the logs themselves. For these, there is only indirect evidence of association with wood: the whelks can either have been washed off from the logs during hauling or be free dwellers and their co-occurrence with sunken wood be fortuitous. Also it is possible that whelks spend only part of their life cycle on wood, being free roamers during most of their life. This is known in Aulacofusus hiranoi and A. coerulescens, the juveniles of which live on sunken wood. It is also interesting to record that traps containing wood and protected by a netting with $3 \mathrm{~mm}$ mesh, deployed in deep water off Santo, Vanuatu (Samadi et al., 2010), were recovered with Manaria specimens, as well as Calagrassor aldermenensis (unpublished data), suggesting that the association of Manaria with wood is not just fortuitous.

Several other groups of molluscs (e.g., chitons, Pectinodonta, cocculinids, mytilids, Pholadoidea) also diversified on biogenic substrates, but for many of them we lack the comprehensive molecular phylogenies that are necessary to place the wood-associated taxa in perspective. In mytilids, wood is certainly the ancestral state, followed by several colonization events to other biogenic substrates - whale carcasses, cold seeps or hydrothermal vents (Lorion et al., 2010). The pattern observed in Buccinidae is much cruder, but it is nevertheless noteworthy that species exclusively associated with vents and seeps and species found on or with sunken wood are closely related, although this relationships needs to be thoroughly tested in a larger phylogenetic context, also supporting a non-fortuitous association with sunken-wood.

\section{ACKNOWLEDGMENTS}

The work was conducted in Paris by Yu.I.K. under the MNHN visiting curatorship programme. He expresses his thanks to Virginie Heros, Barbara Buge, Philippe Maestrati and Pierre Lozouet for assistance during his stays in Paris. Anders Warén provided samples of tissues of Thermosipho auzendei. The MarBOL project in the MNHN is a joint effort with funding from (1) the Alfred P. Sloan Foundation, PI D. Steinke, co-PIs P. Bouchet and S. Samadi; (2) the Consortium National de Recherche en Génomique and the Service de Systématique Moléculaire (UMS 2700 CNRS-MNHN), part of the agreement 2005/67 between the Genoscope and MNHN on the project Macrophylogeny of Life directed by G. Lecointre; (3) the ATM Barcode (PIs: S. Samadi and J.N. Labat); (4) the Fondation pour la Recherche sur la Biodiversité; and (5) the EDIT program. This work was partially supported by the grant of RFBR 11-04-01284-a 'Evolution of digestive system of carnivorous gastropods: testing of morphologically-based hypotheses by molecular data' (PI Yu. Kantor). We want to express our thanks to anonymous referees for their valuable comments and suggestions.

\section{References}

Beck L. A. (1996). Systematic position and relationship of Phymorhynchus hyfifluxi n.sp., a further new turrid gastropod species associated with hydrothermal vent sites in the North Fiji Basin. Archiv für Molluskenkunde 126: 109-115.

Bouchet P. and Rocroi J.-P. (2005) Classification and nomenclator of gastropod families. Malacologia 47, 1-397. 
Bouchet P. and Warén A. (1986) Mollusca Gastropoda: Taxonomical notes on tropical deep water Buccinidae with descriptions of new taxa. Mémoires du Muséum national d'Histoire naturelle, ser. A, Zoologie, 133: 455-499, pls 1-18.

Desbruyères D., Sagonzac M. and Bright M. (eds). 2006. Handbook of deep-sea hydrothermal vent fauna. Second completely revised edition. Denisia 18, 1-544.

Folmer O., Black M., Hoeh W., Lutz R. and Vrijenhoek R. (1994) DNA primers for amplification of mitochondrial cytochrome c oxidase subunit I from diverse metazoan invertebrates. Molecular Marine Biology and Biotechnology 3, 294-299.

Fraussen K. (2008) Enigmaticolus, a new genus of deep water buccinids (Gastropoda: Buccinidae), with description of a new species from Madagascar. Gloria Maris 46(4-5), 74-82.

Fraussen K. and Hadorn R. (2005) A new species of Eosipho (Gastropoda: Buccinidae) from Guadeloupe, western Atlantic. Novapex 6(4), 107-109.

Fraussen K. and Sellanes J. (2008) Three new buccinid species (Gastropoda: Neogastropoda) from Chilean deep-water, including one from a methane seep. The Veliger 50(2), 97-106.

Génio L., Kiel S., Cunha M.R., Grahame J. and Little C.T.S. (2012) Shell microstructures of mussels (Bivalvia: Mytilidae: Bathymodiolinae) from deep-sea chemosyntheticsites: Do they have a phylogenetic significance? Deep-Sea Research I 64, 86-103.

Hasegawa K. (2009) Upper bathyal gastropods of the Pacific coast of northern Honshu, Japan, chiefly collected by R/V Wakataka-maru. In: Fujita T. (ed.). Deep-sea fauna and pollutants off Pacific coast of northern Japan, National Museum of Nature and Science Monographs, 39, 225-383.

Huelsenbeck J.P., Ronquist F. and Hall B. (2001) MrBayes: bayesian inference of phylogeny. Bioinformatics 17, 754-755.

Jovelin R. and Justine J.-L. (2001) Phylogenetic relationships within the Polyopisthocotylean monogeneans (Plathyhelminthes) inferred from partial 28S rDNA sequences. International Journal of Parasitology 31, 393-401.

Kantor Yu.I. (1988) Gastropods of the subgenus Ancistrolepis (Clinopegma) (Gastropoda, Buccinidae) of the Okhotsk Sea. Zoological Journal 67(8), 1126-1140 [In Russian].

Kantor Yu.I., Puillandre N., Rivasseau A. and Bouchet P. (2012) Neither a buccinid nor a turrid: A new family of deep-sea snails for Belomitra P. Fischer, 1883 (Mollusca, Neogastropoda), with a review of Recent Indo-Pacific species. Zootaxa 3496, 1-64.

Kosyan A. R. and Kantor Yu. I. (2009) Phylogenetic analysis of the subfamily Colinae (Neogastropoda: Buccinidae) based on morphological characters. The Nautilus 123(3), 8394.

Lallier F.H. (2006) Thioautotrophic symbiosis: towards a new step in eukaryote evolution? Cahiers de Biologie Marine 47, 391-396.

Lorion J., Buge B., Cruaud C. and Samadi S. (2010) New insights into diversity and evolution of deep-sea Mytilidae (Mollusca: Bivalvia). Molecular Phylogenetics and Evolution 57, 71-83.

Marshall B.A. (1985) Recent and Tertiary deep-sea limpets of the genus Pectinodonta Dall (Mollusca: Gastropoda) from New Zealand and New South Wales. New Zealand Journal of Zoology 12, 273-282.

Marshall B.A. (1986) Recent and Tertiary Cocculinidae and Pseudococculinidae (Mollusca: Gastropoda) from New Zealand and New South Wales. New Zealand Journal of Zoology 12, 505-546.

Marshall B.A. (1988) Skeneidae, Vitrinellidae and Orbitestellidae (Mollusca: Gastropoda) associated with biogenic substrata from bathyal depths off New Zealand and New South Wales. Journal of Natural History 22, 949-1004.

Martell K.A., Tunnicliffe V. and Macdonald I.R. (2002) Biological features of a buccinid whelk (Gastropoda, Neogastropoda) at the Endeavour ventfields of Juan de Fuca Ridge, northeast Pacific. Journal of Molluscan Studies 68(1), 45-53. 
Okutani T. and Iwasaki N. (2003) Noteworthy abyssal mollusks (excluding vesicomyid bivalves) collected from the Nankai Trough off Shikoku by the ROV Kaiko of the Japan Marine Science and Technology Center. Venus 62(1-2), 1-10.

Rambaut A., Drummond A.J. (2007) Tracer v1.4. Available from http://beast.bio.ed.ac.uk/Tracer

Samadi S., Corbari L., Lorion J., Hourdez S., Haga T., Dupont J., Boisselier M.-C. and Richer De Forges B. (2010) Biodiversity of deep-sea organisms associated with sunken-wood or other organic remains sampled in the tropical Indo-Pacific. Cahiers de Biologie Marine 50, 343-352.

Sasaki T., Okutani T. and Fujikura K. (2005) Molluscs from hydrothermal vents and cold seeps in Japan: a review of taxa recorded in twenty recent years (1984-2004). Venus 64(34), 87-133.

Sasaki T., Warén A., Kano Y., Okutani T., and Fujikura K. (2010). Gastropods from Recent hot vents and cold seeps: systematics, diversity and life strategies. In Kiel S. (ed.) The Vent and Seep Biota, Topics in Geobiology 33. Springer, pp. 170-254.

Simon C., Franke A. and Martin A. (1991) The polymerase chain reaction: DNA extraction and amplification. In Hewitt G.M., Johnson A.W.B. and Young J.P.W. (eds) Molecular techniques in taxonomy. Springer-Verlag, New York, pp. 329-355.

Warén A. (2011) Molluscs on biogenic substrates. In Bouchet P., Le Guyader H. and Pascal O. (eds), The Natural History of Santo. Patrimoines Naturels, 70: 438-448.

Warén A. and Bouchet P. (1989) New gastropods from East Pacific hydrothermal vents. Zoologica Scripta 18, 67-102.

Warén A. and Bouchet P. (1993) New records, species, genera and a new family of gastropods from hydrothermal vents and hydrocarbon seeps. Zoologica Scripta 22, 1-90.

Warén A. and Bouchet P. (2001) Gastropoda and Monoplacophora from hydrothermal vents and seeps; new taxa and records. The Veliger 44, 116-231.

Wolff T. (1979) Macrofaunal utilization of plant remains in the deep sea. Sarsia 64, 117-136. 
Figure captions.

Fig. 1. Bayesian phylogenetic tree obtained with the COI gene. Posterior probabilities $>0.80$ are indicated for each node. Shells of sequenced specimens (except Thermosipho auzendei, for which the holotype is illustrated) are illustrated for comparison.

Fig. 2. Bayesian phylogenetic tree obtained with the $12 \mathrm{~S}$ gene. Posterior probabilities $>0.80$ are indicated for each node. Shells of sequenced specimens (except Thermosipho auzendei, for which the holotype is illustrated) are illustrated for comparison.

Fig. 3. Bayesian phylogenetic tree obtained with the $28 \mathrm{~S}$ gene. Posterior probabilities $>0.80$ are indicated for each node. Shells of sequenced specimens are illustrated for comparison.

Fig. 4. Bayesian phylogenetic tree obtained with the COI, 12S and 28S gene. Posterior probabilities $>0.80$ are indicated for each node. Shells of sequenced specimens (except Thermosipho auzendei, for which the holotype is illustrated) are illustrated for comparison.

Fig. 5. Enigmaticolus monnieri Fraussen, 2008. (A-B) holotype, MNHN 20464, SL 63.7 mm; (C) MNHN IM-2009-7078, SL 76.5 mm; (D-F) MNHN IM-2009-7079, SL 99.4 mm.

Fig. 6. Soft body morphology of Enigmaticolus monnieri Fraussen, 2008. (A-D) IM-20097078: (A) dorsal, (B) lateral, and (C) ventral views of the body; (D) mantle; (E-F) radula (IM2009-7079). Abbreviations: cme - cut mantle edge; col.m - columellar muscle; ct - ctenidium; dg - digestive gland; eye - eye; hd - hypobranchial gland; ne - nephridium; op - operculum; os - osphradium; per - pericardium; re - rectum; s - siphon; sf - siphonal fold; st - stomach; tn tentacle.

Fig. 7. Digestive and reproductive systems of Enigmaticolus monnieri Fraussen, 2008 (IM2009-7079). (A) organs of anterior foregut, left view, rhynchodaeum (=proboscis sheath) dissected and proboscis exposed; (B) anterior oesophagus with valve of Leiblein, circumoesophageal nerve ring and part of right salivary gland, right view; (C) outer view of the stomach; (D) penis. Abbreviations: aoe - anterior oesophagus; crop - crop; dgg - ducts of the digestive gland; dL - gland of Leiblein; lsd - duct of left salivary gland; lsg - left salivary gland; $\mathrm{nr}$ - circumoesophageal nerve ring; poe - posterior oesophagus poe - posterior oesophagus; $\mathrm{pr}$ proboscis; prr - proboscis retractors; rsg - right salivary gland; vL - valve of Leiblein.

Fig. 8. Calagrassor aldermenensis (Powell, 1971). (A-B) live snails on the sunken log, MIRIKY, st. CP 3290; (C) ventral and (D) dorsal views of the body; (E) mantle. Abbreviations: see on Fig. 6.

Fig. 9. Digestive system of Calagrassor aldermenensis (Powell, 1971). (A) organs of anterior foregut, left view, rhynchodaeum (=proboscis sheath) dissected and proboscis exposed; (B) anterior oesophagus with valve of Leiblein, circumoesophageal nerve ring, right salivary gland and part of gland of Leiblein, right view; (C) visceral mass with the stomach. Abbreviations: adg - anterior digestive gland; anrh - anterior thick portion of rhynchodaeum; cae - caecum of posterior oesophagus; ht - heart; pdg - posterior digestive gland; psrh- posterior thin portion of rhynchodaeum; rm - rhynchodaeum retractor muscle; ts - testis. Other abbreviations see on Fig. 7. 
Table 1. List of specimens

Genus

species

Calagrassor gen. nov.

Calagrassor gen. nov.

Calagrassor gen. nov.

Calagrassor gen. nov.

Calagrassor gen. nov.

Calagrassor gen. nov.

Calagrassor gen. nov. sp. 1

Calagrassor gen. nov.

Enigmaticolus

Enigmaticolus

Eosipho

Eosipho

Eosipho

Eosipho

Eosipho

Eosipho

Eosipho

Gaillea gen. nov aldermenensis

(Powell, 1971)

aldermenensis

(Powell, 1971)

aldermenensis

(Powell, 1971)

aldermenensis

(Powell, 1971)

aldermenensis

(Powell, 1971)

aldermenensis

(Powell, 1971)

sp. 1

monnieri Fraussen

2008

monnieri Fraussen

2008

smithi (Schepman,

1911)

smithi (Schepman,

1911)

smithi (Schepman,

1911)

smithi (Schepman,

1911)

smithi (Schepman,

1911)

smithi (Schepman,

1911)

sp. 1

coriolis (Bouchet et

Warén, 1986)
Institutional registration

number

MNHN IM-2007-32962

MNHN IM-2007-32963

MNHN IM-2007-34635

MNHN IM-2007-34653

MNHN IM-2007-34656

MNHN IM-2007-34657

MNHN IM-2007-32940

MNHN IM-2007-35739

MNHN IM-2009-7078

MNHN IM-2009-7079

MNHN IM-2007-32711

MNHN IM-2007-32714

MNHN IM-2007-32715

MNHN IM-2007-32716

MNHN IM-2007-32907

MNHN IM-2007-32983

MNHN IM-2007-32921

MNHN IM-2007-34637
Locality, Expedition, Station and depth

Bold ID

COI

12S

Solomon Islands, SALOMON 2, st. CP2213, $7^{\circ} 39^{\prime} \mathrm{S}, 157^{\circ} 43^{\prime} \mathrm{E}, 495-650 \mathrm{~m}$

Solomon Islands, SALOMON 2, st. CP2213, $7^{\circ} 39$ 'S, $157^{\circ} 43^{\prime} \mathrm{E}, 495-650 \mathrm{~m}$ Philippines, AURORA 2007, St. CP2732,

$15^{\circ} 27^{\prime} \mathrm{N}-121^{\circ} 36^{\prime} \mathrm{E}, 556 \mathrm{~m}$

Philippines, AURORA 2007, St. CP2673,

$15^{\circ} 01$ 'N, $121^{\circ} 45^{\prime} \mathrm{E}, 431-493 \mathrm{~m}$

Philippines, AURORA 2007, St. CP2657,

$16^{\circ} 01^{\prime} \mathrm{N}, 121^{\circ} 51^{\prime} \mathrm{E}, 342-358 \mathrm{~m}$

Philippines, AURORA 2007, St. CP2730,

$15^{\circ} 21^{\prime} \mathrm{N}, 121^{\circ} 34^{\prime} \mathrm{E}, 358-378 \mathrm{~m}$

Philippines, PANGLAO 2005, St. CP2386, $8^{\circ} 49^{\prime} \mathrm{N}, 123^{\circ} 02^{\prime} \mathrm{E}, 2120-2149 \mathrm{~m}$

Philippines, PANGLAO 2005, St. CP2356, $9^{\circ} 21^{\prime} \mathrm{N}, 124^{\circ} 09^{\prime} \mathrm{E}, 1764 \mathrm{~m}$

Madagascar, MIRIKY, st. CP3279, 15²2’S, 455’'E, 780-1020 m

Madagascar, MIRIKY, st. CP3270, 15³1'S, 454'ㄹ, $800 \mathrm{~m}$

Solomon Islands, SALOMON 2, St. CP2184, $8^{\circ} 17 ' \mathrm{~S}, 160^{\circ} 00^{\prime} \mathrm{E}, 464-523 \mathrm{~m}$

Solomon Islands, SALOMON 2, st. CP2213,

$7^{\circ} 39^{\prime} \mathrm{S}, 157^{\circ} 43^{\prime} \mathrm{E}, 495-650 \mathrm{~m}$

Solomon Islands, SALOMON 2, st. CP2213, $7^{\circ} 39^{\prime} \mathrm{S}, 157^{\circ} 43^{\prime} \mathrm{E}, 495-650 \mathrm{~m}$

Solomon Islands, SALOMON 2, st. CP2213, $7^{\circ} 39^{\prime} \mathrm{S}, 157^{\circ} 43^{\prime} \mathrm{E}, 495-650 \mathrm{~m}$

Vanuatu, SANTO 2006, St. AT59, 15³2'S,

$167^{\circ} 22^{\prime} \mathrm{E}, 759-985 \mathrm{~m}$

Vanuatu, SANTO 2006, St. AT103, $15^{\circ} 01^{\prime} S$

$166^{\circ} 52^{\prime} \mathrm{E}, 721-773 \mathrm{~m}$

Solomon Islands, SALOMON 2, St. CP2197, $8^{\circ} 24^{\prime} \mathrm{S}, 159^{\circ} 22^{\prime} \mathrm{E}, 897-1057 \mathrm{~m}$

Philippines, AURORA 2007, St. CP2699,

$14^{\circ} 50^{\prime} \mathrm{N}, 123^{\circ} 35^{\prime} \mathrm{E}, 541-583 \mathrm{~m}$
NEOGA652- KC756035

10

NEOGA653- KC756036 KC756013

NEOGA778-

10

KC756037 KC756014

KC755997

NEOGA786-

10

KC756040

EOGA787-

10

KC756039

NEOGA788-

10

KC756038

NEOGA641-

10

KC756063

NEOGA845-

10

KC756047

KC756017

KC755999

NEOGA1056-

10

KC756033

KC756011

NEOGA1057

$$
10
$$

KC756034

KC756012

KC755996

OGA564

10

KC756044

KC756016

KC755998

NEOGA566-

10

KC756043

NEOGA567-

10

KC756042 KC756015

NEOGA568-

10

KC756045

NEOGA627-

10

KC756048

KC756018

KC756000

NEOGA662-

10

KC756041

NEOGA633-

10

KC756046

NEOGA779-

10

KC756030
$28 S$

. 
Manaria

Manaria

Manaria

Manaria

Manaria

Manaria

Manaria

Manaria

Manaria

Manaria

Manaria

Manaria

Manaria

Manaria

Manaria

Manaria

Manaria

Thermosipho gen.

nov.

Thermosipho gen.

nov. aff. brevicaudata (Schepman, 1911) brevicaudata

(Schepman, 1911)

brevicaudato

(Schepman, 1911)

brevicaudata

(Schepman, 1911)

brevicaudata

(Schepman, 1911)

brevicaudata

(Schepman, 1911)

brevicaudata

(Schepman, 1911)

clandestina Bouchet

\& Warén, 1986

clandestina Bouchet

\& Warén, 1986

clandestina Bouchet

\& Warén, 1986

clandestina Bouchet

\& Warén, 1986

clandestina Bouchet

\& Warén, 1986

kuroharai Azuma,

1960

sp. 1

sp. 2

sp. 3

sp. 4

auzendei (Warén et

Bouchet, 2001)

auzendei (Warén et

Bouchet, 2001)
MNHN IM-2007-34645

MNHN IM-2007-32952

MNHN IM-2007-32953

MNHN IM-2007-32954

MNHN IM-2007-32972

MNHN IM-2007-32973

MNHN IM-2007-32984

MNHN IM-2007-32864

MNHN IM-2007-32865

MNHN IM-2007-32866

MNHN IM-2007-34642

MNHN IM-2007-34647

MNHN IM-2007-32976

MNHN IM-2007-32668

MNHN IM-2007-32880

MNHN IM-2007-32878

MNHN IM-2007-32881

SMNH 45478

SMNH 81800
Philippines, AURORA 2007, St. CP2703,

$15^{\circ} 02^{\prime} \mathrm{N}, 123^{\circ} 11^{\prime} \mathrm{E}, 1191-1262 \mathrm{~m}$

Solomon Islands, SALOMON 2, st. CP2219,

$7^{\circ} 58^{\prime} \mathrm{S}, 157^{\circ} 34^{\prime} \mathrm{E}, 650-836 \mathrm{~m}$

Solomon Islands, SALOMON 2, st. CP2219, 758'S, 157³4'E, 650-836 m

Solomon Islands, SALOMON 2, st. CP2219, $7^{\circ} 58$ 'S, $157^{\circ} 34^{\prime} \mathrm{E}, 650-836 \mathrm{~m}$

Solomon Islands, SALOMON 2, st. CP2215,

$7^{\circ} 44^{\prime} \mathrm{S}, 157^{\circ} 42$ 'E, 718-880 m

Solomon Islands, SALOMON 2, st. CP2215 $7^{\circ} 44^{\prime} \mathrm{S}, 157^{\circ} 42^{\prime} \mathrm{E}, 718-880 \mathrm{~m}$

Solomon Islands, SALOMON 2, st. CP2179, $8^{\circ} 49^{\prime} \mathrm{S}, 159^{\circ} 43^{\prime} \mathrm{E}, 765-773 \mathrm{~m}$

Philippines, PANGLAO 2005, St. CP2389,

$9^{\circ} 28^{\prime} \mathrm{N}, 123^{\circ} 38^{\prime} \mathrm{E}, 784-786 \mathrm{~m}$

Philippines, PANGLAO 2005, St. CP2396 $9^{\circ} 36^{\prime} \mathrm{N}, 123^{\circ} 42^{\prime} \mathrm{E}, 609-673 \mathrm{~m}$

Philippines, PANGLAO 2005, St. CP2389, $9^{\circ} 28^{\prime} \mathrm{N}, 123^{\circ} 38^{\prime} \mathrm{E}, 784-786 \mathrm{~m}$

Philippines, AURORA 2007, St. CP2730,

$15^{\circ} 21^{\prime} \mathrm{N}, 121^{\circ} 34^{\prime} \mathrm{E}, 358-378 \mathrm{~m}$

Philippines, AURORA 2007, St. CP2729,

$15^{\circ} 20^{\prime} \mathrm{N}, 121^{\circ} 37^{\prime} \mathrm{E}, 593-600 \mathrm{~m}$

Solomon Islands, SALOMON 2, st. CP2227, $6^{\circ} 37^{\prime} \mathrm{S}, 156^{\circ} 13^{\prime} \mathrm{E}, 508-522 \mathrm{~m}$

Solomon Islands, SALOMON 2, st. CP2288,

$8^{\circ} 36^{\prime} \mathrm{S}, 157^{\circ} 26^{\prime} \mathrm{E}, 509-520 \mathrm{~m}$

Solomon Islands, SALOMON 2, st. CP2195, $8^{\circ} 26^{\prime} \mathrm{S}, 159^{\circ} 26^{\prime} \mathrm{E}, 543-593 \mathrm{~m}$

Solomon Islands, SALOMON 2, st. CP2195, $8^{\circ} 26^{\prime} \mathrm{S}, 159^{\circ} 26^{\prime} \mathrm{E}, 543-593 \mathrm{~m}$

Solomon Islands, SALOMON 2, st. CP2195, $8^{\circ} 26^{\prime} \mathrm{S}, 159^{\circ} 26^{\prime} \mathrm{E}, 543-593 \mathrm{~m}$

East Pacific Rise, Naudur, st.ND12-7-7B

Animal Farm Site, $18^{\circ} 36,5^{\prime}$ S, $113^{\circ} 23,98^{\prime} \mathrm{W}$, $2673 \mathrm{~m}$

Eacific Rise, Alvin, dive 3339

31 ${ }^{\circ} 09,53 ' \mathrm{~S}, 111^{\circ} 59,95^{\prime} \mathrm{W}, 2338 \mathrm{~m}$
NEOGA784-

KC756049 KC756019

KC756022

KC756055

KC75602

10

KC756054

K756021

10

10

KC756050 KC756020

NEOGA657-

10

KC756053

NEOGA658-

10

KC756052

NEOGA663-

10

KC756051

NEOGA608-

10

KC756058

KC756024

KC756004

NEOGA609-

10

KC756065 KC756029

KC756009

KC756057 KC756023

NEOGA782-

10

KC756056

NEOGA785

10

KC756059

NEOGA660-

10

KC756032

NEOGA541-

10

KC75606

KC756026

KC756006

NEOGA614

10

KC756062 KC756027

KC756007

10

KC756060 KC756025

KC756005

NEOGA615-

10

KC756064 KC756028

KC756008

KC687074 KC687072

KC687075 KC687073
KC756001

KC756003

KC756002

(n) 
Conasprella

Metula eugrammata $\mathrm{f}$.

nereis Petuch, 1979

sp.
MNHN IM-2007-17922

MNHN IM-2007-30079
Philippines, PANGLAO 2005, St. CP2400, $9^{\circ} 32^{\prime} \mathrm{N}, 123^{\circ} 42^{\prime} \mathrm{E}, 111-115 \mathrm{~m}$

Philippines, PANGLAO 2005, St. CP2348,

$9^{\circ} 30^{\prime} \mathrm{N}, 123^{\circ} 52^{\prime} \mathrm{E}, 196-216 \mathrm{~m}$
CONO339-08

NEOGA239-

10
EU015734 EU685782

KC756067 KC756031
EU015619

KC756010 


\section{H IM 200717922 Conasprella eugrammata f. nereis}

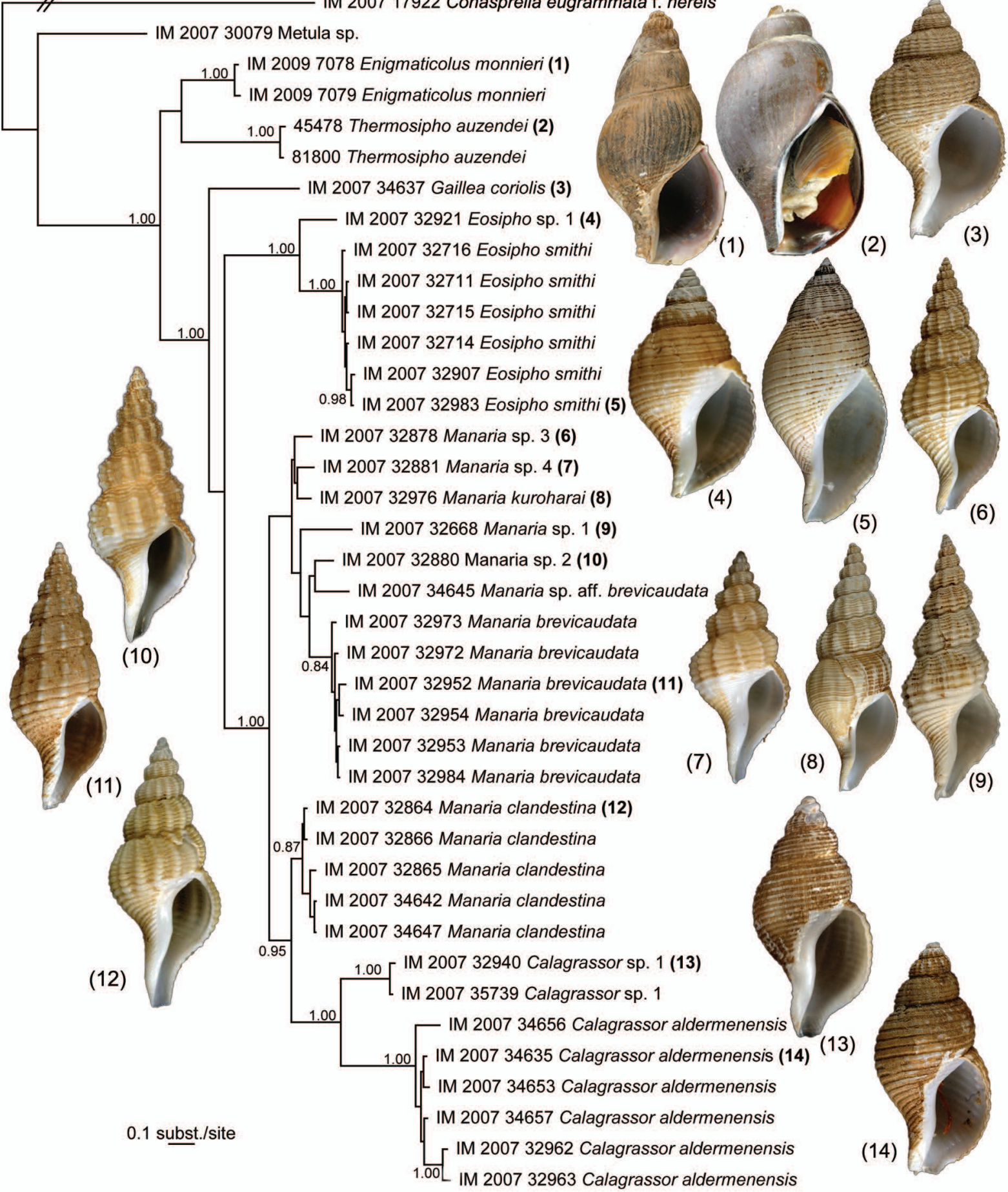




\section{H IM 200717922 Conasprella eugrammata f. nereis}
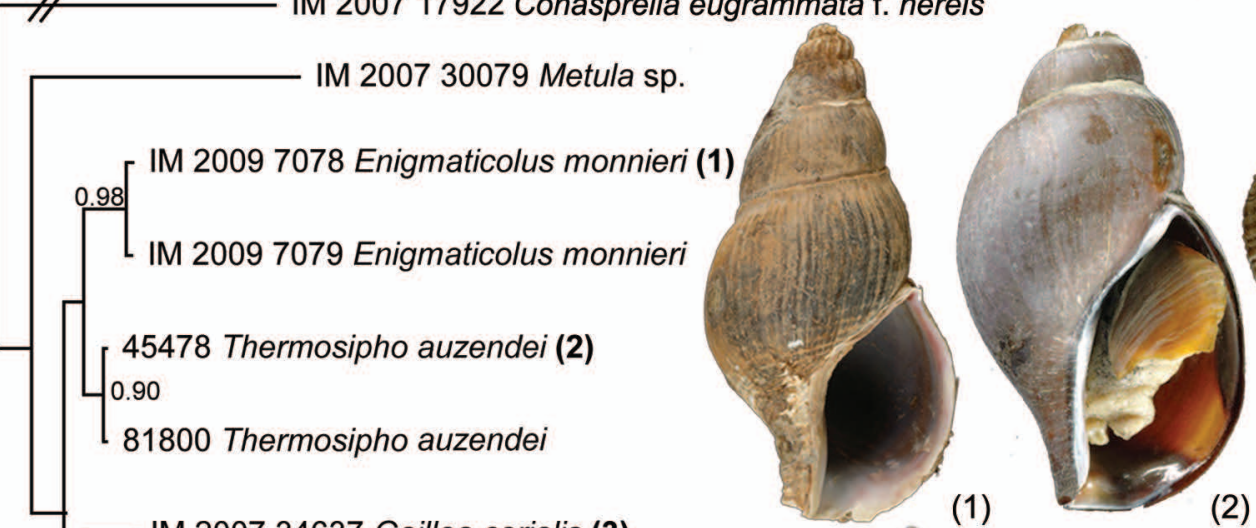

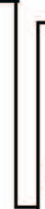

IM 200734637 Gaillea coriolis (3)

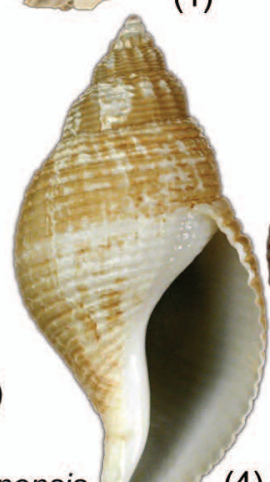

4

$\left[\begin{array}{l}\text { IM } 200732907 \text { Eosipho smithi (4) } \\ \text { IM } 200732711 \text { Eosipho smithi } \\ \text { IM } 200732715 \text { Eosipho smithi }\end{array}\right.$

0.89 IM 200735739 Calagrassor sp. 1

$1(5)$

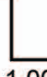

[ IM 200732963 Calagrassor aldermenensis

is (6)

(4)

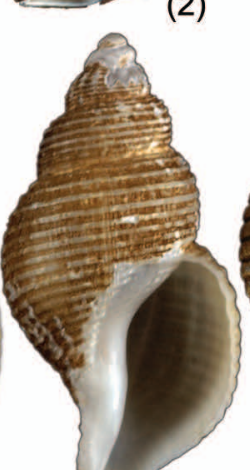

(5)

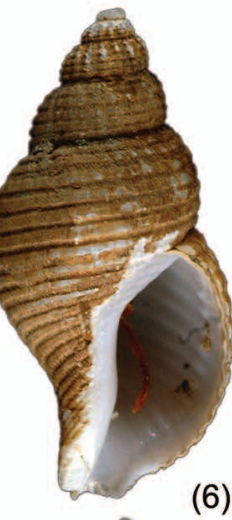

1.00 L IM 200734635 Calagrassor aldermenensis (6)

[ IM 200732952 Manaria brevicaudata (7)

IM 200732953 Manaria brevicaudata

IM 200732954 Manaria brevicaudata

— IM 200734645 Manaria sp. aff. brevicaudata

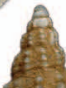

(6)

[ IM 200732668 Manaria sp. 1 (8)

(7)

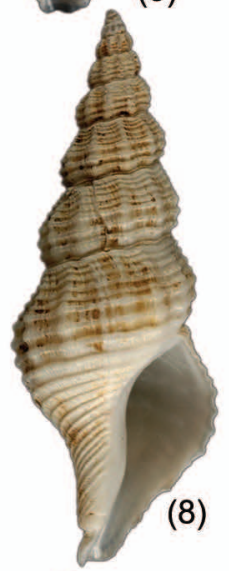

(3)

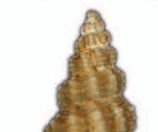

L IM 200732880 Manaria sp. 2 (9)

ᄃ IM 200732878 Manaria sp. 3 (10)

— IM 200732881 Manaria sp. 4 (11)

[ IM 200732865 Manaria clandestina

0.89 I IM 200732864 Manaria clandestina (12) 0.81

L IM 200732866 Manaria clandestina

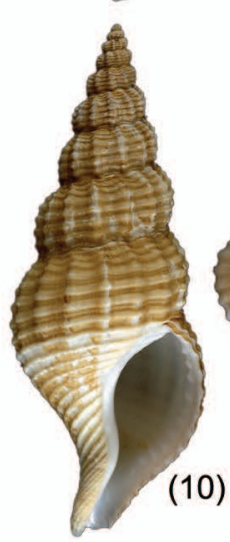

(8)

(9)

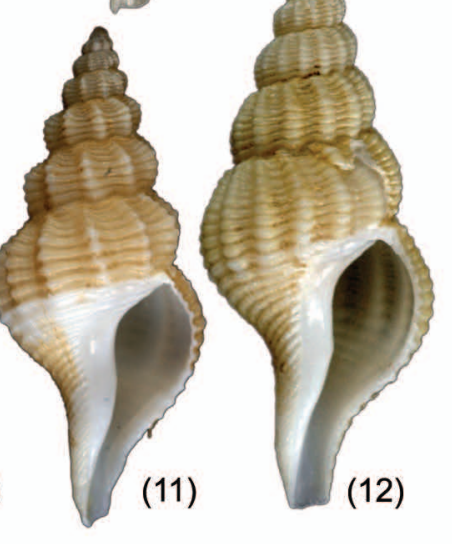




\section{H IM 200717922 Conasprella eugrammata f. nereis}

IM 200730079 Metula sp.

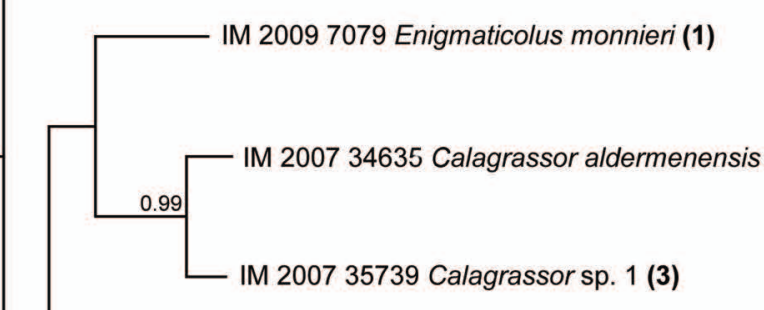

(2)
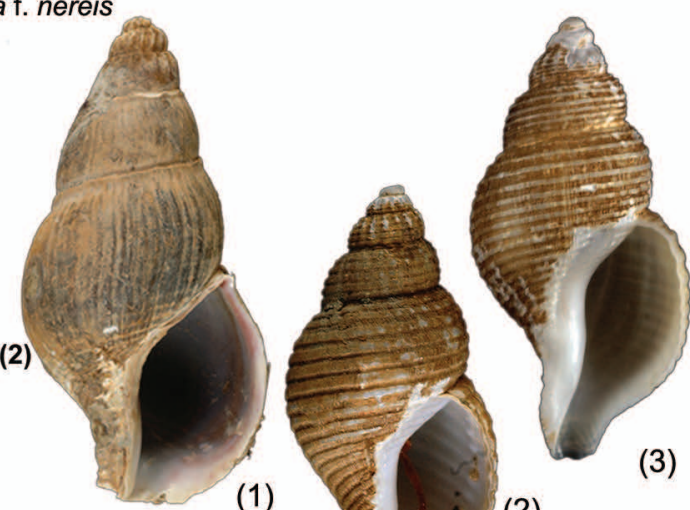

(3)

(2)
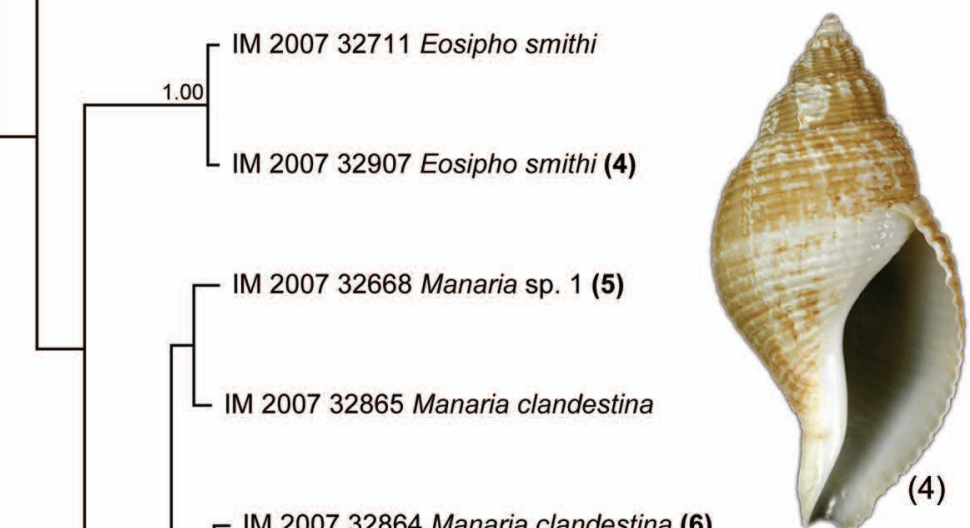

(1)

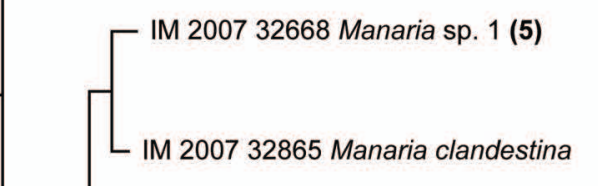

(4)

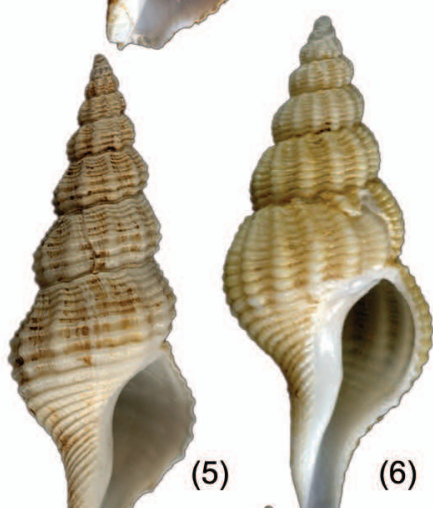

$0.99\left[\begin{array}{l}\text { IM } 200732864 \text { Manaria clandestina (6) } \\ {[}\end{array}\right.$

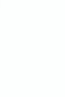

- IM 200732881 Manaria sp. 4 (7)
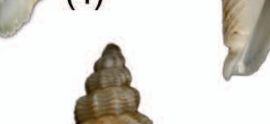

(6)
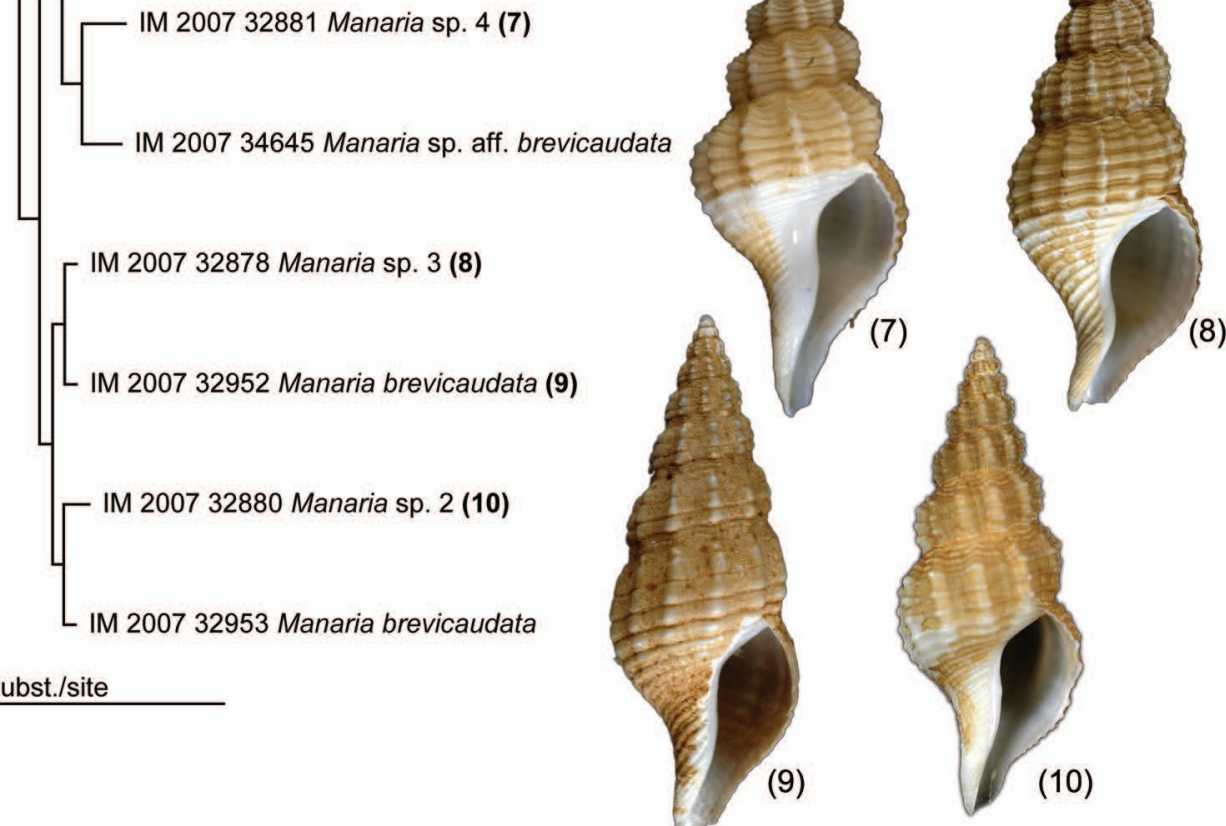

(8) 


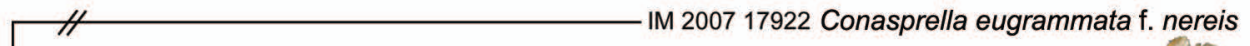

IM 200730079 Metula sp.

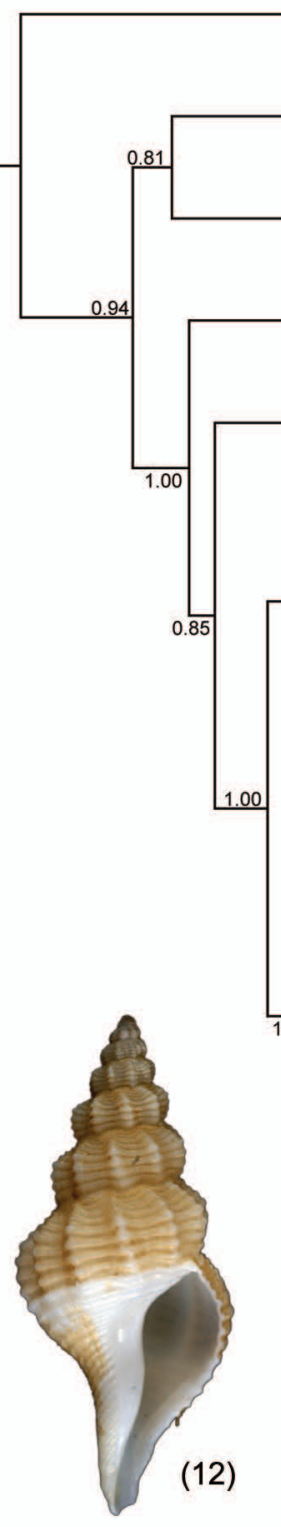

45478 Thermosipho auzendei (1)

IM 20097079 Enigmaticolus monnieri (2)

- IM 200734637 Gaillea coriolis (3)

IM 200732711 Eosipho smithi (4)

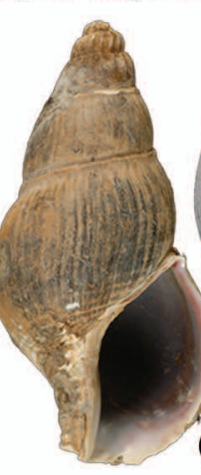

- IM 200732963 Calagrassor aldermenensis

(1)

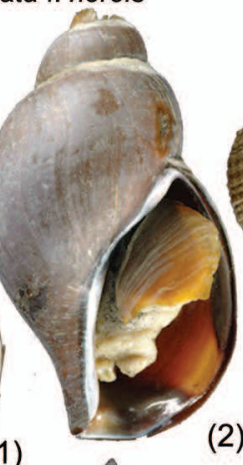

(3)

(5)

IM 200734635 Calagrassor aldermenensis (6)

— IM 200732952 Manaria brevicaudata (7)

00

0.1 subst./site

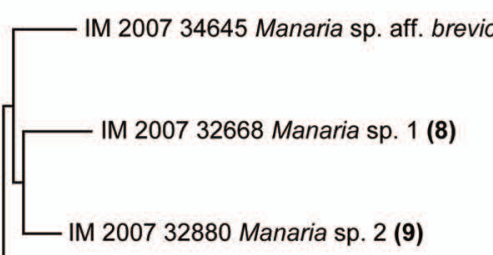

IM 200732881 Manaria sp. 4 (12)

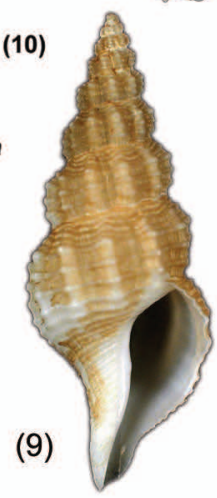

(6)

(4)

_ IM 200732878 Manaria sp. 3 (11)

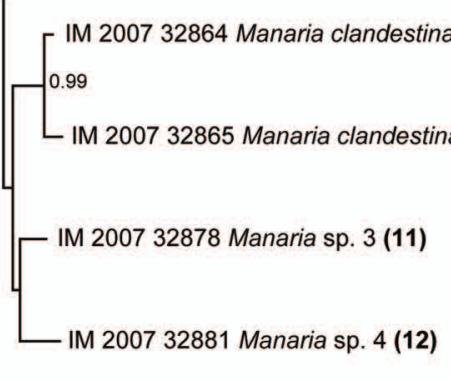

(9)

(10)

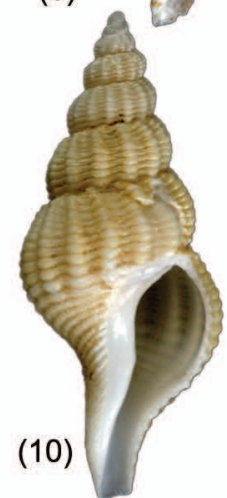

(8)

(7)

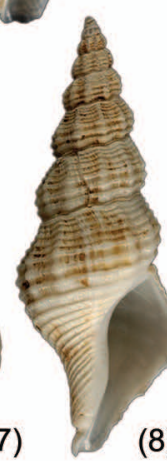

(11)

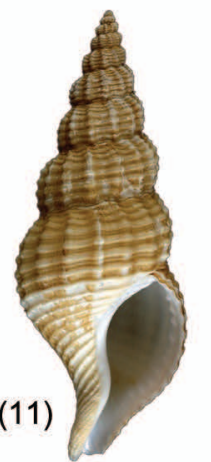




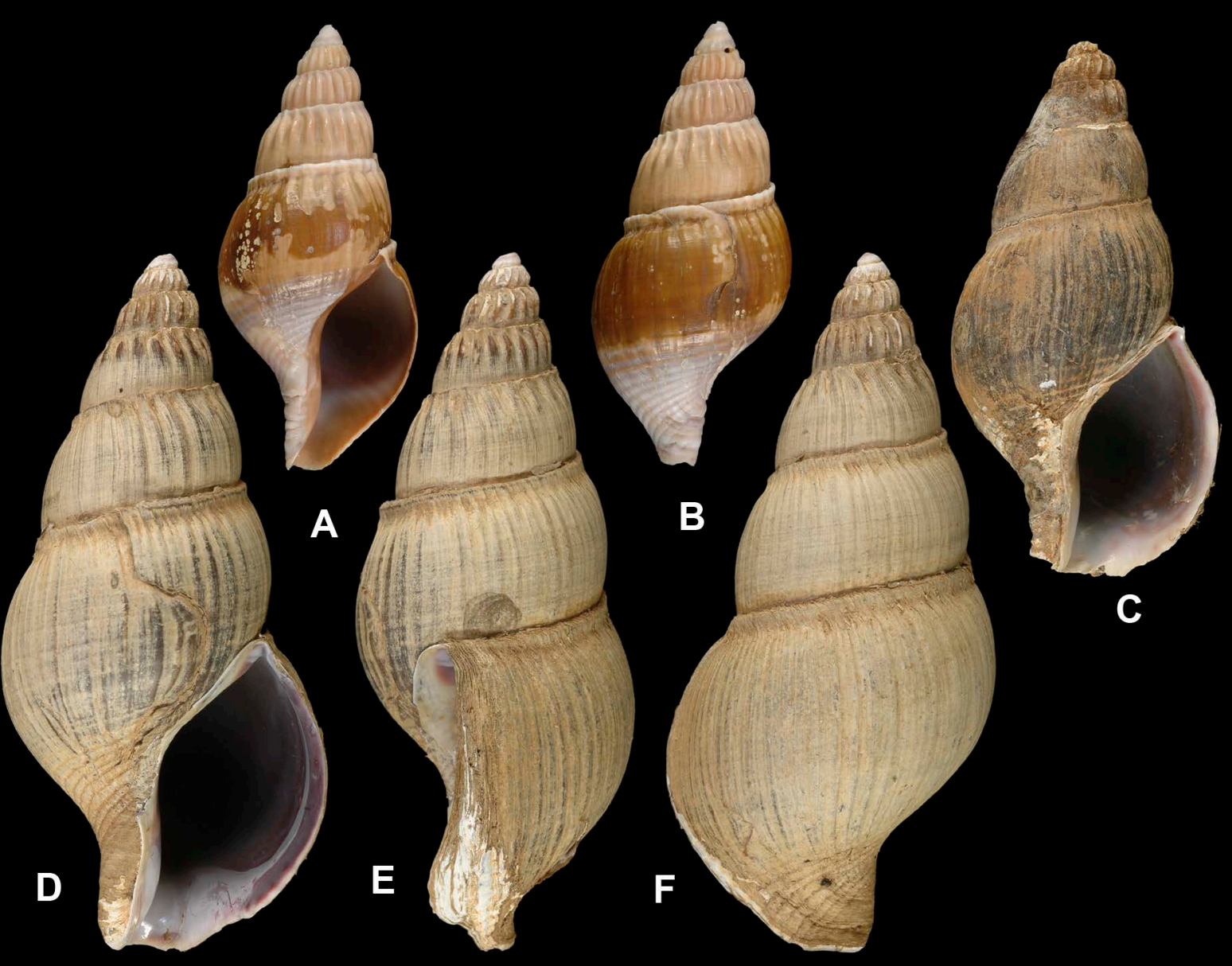



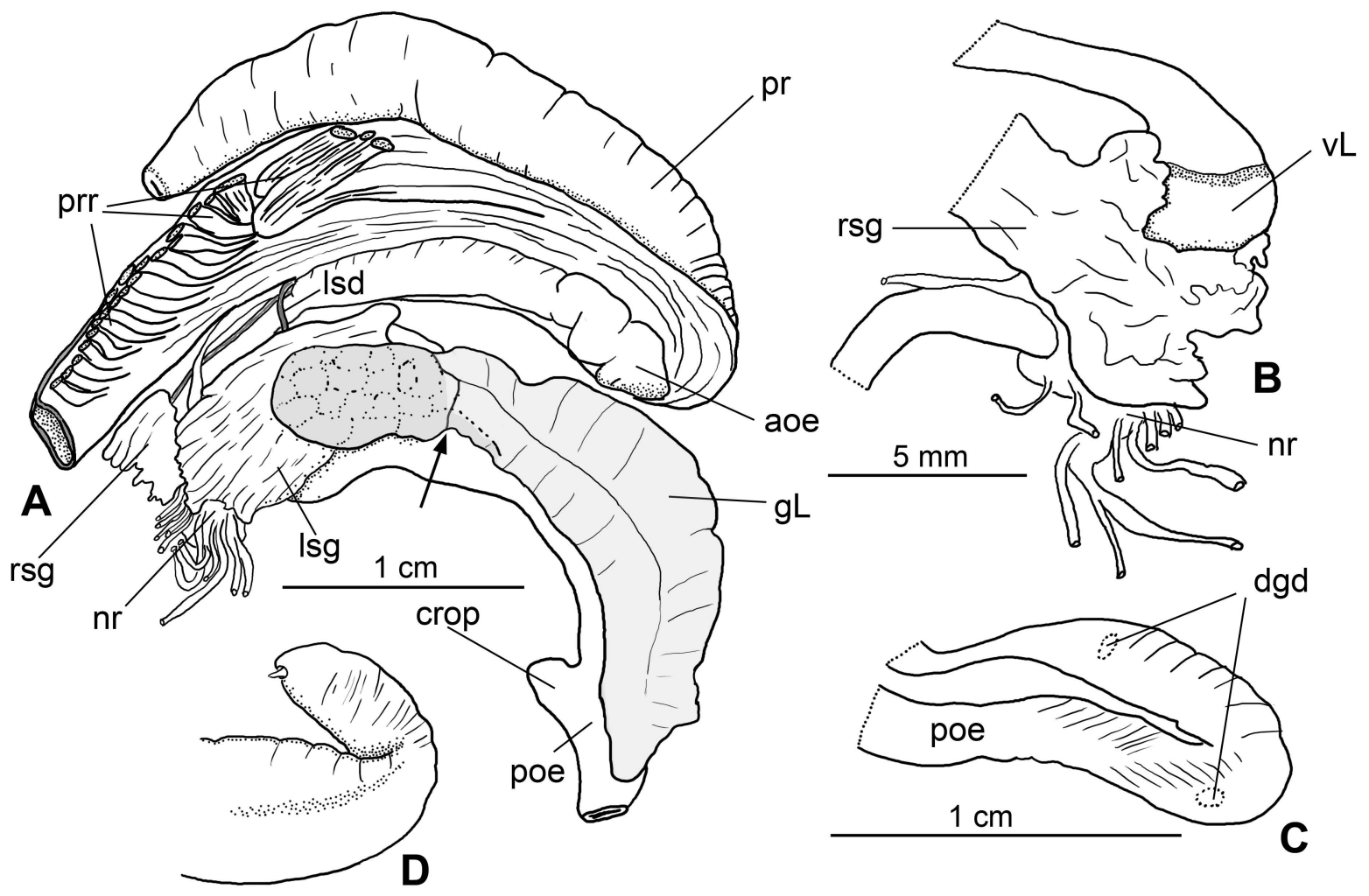


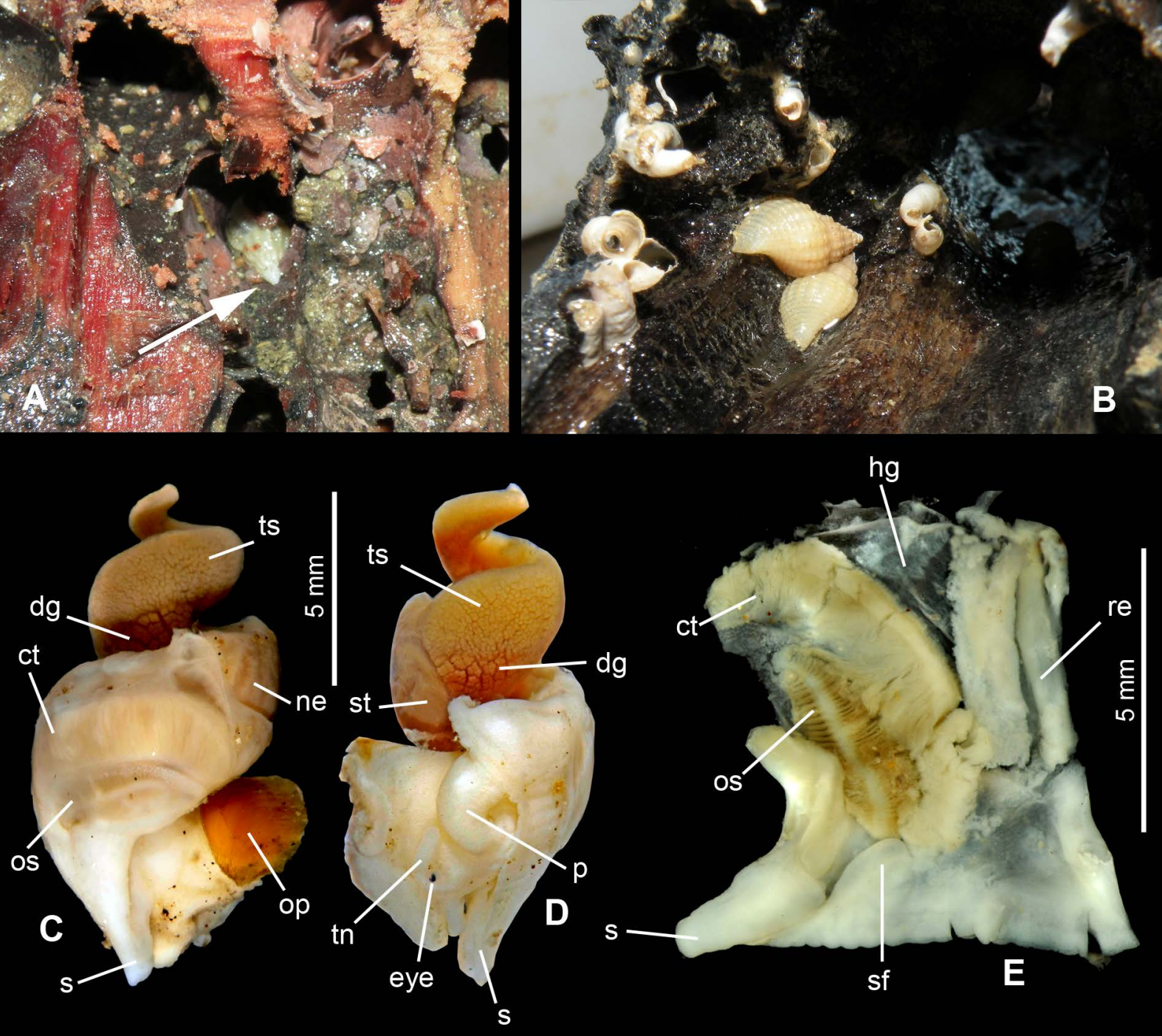




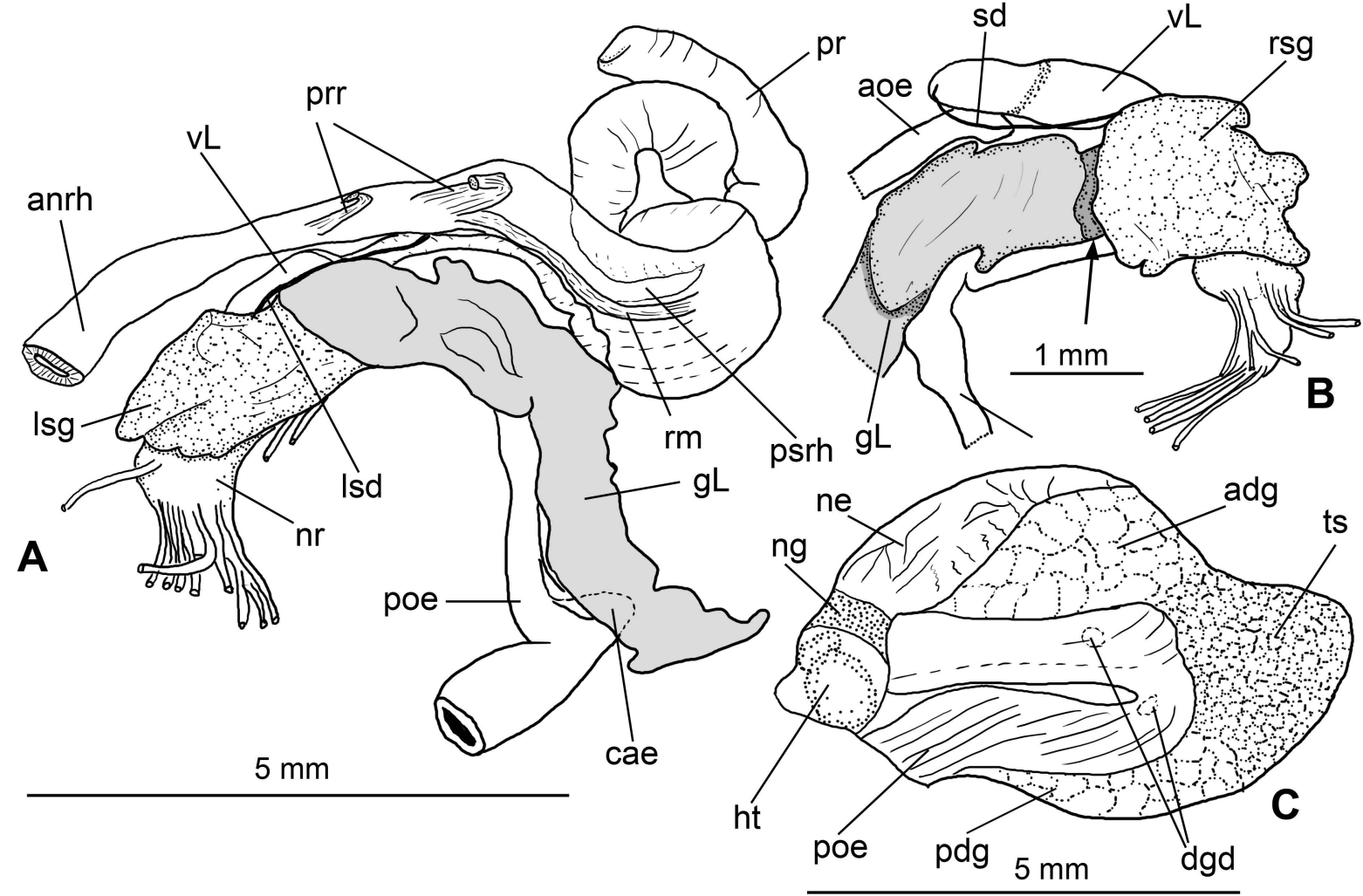

